\title{
Neotectonics, flooding patterns and landscape evolution in southern Amazonia
}

\author{
U. Lombardo \\ Universität Bern, Geographisches Institut, Hallerstrasse 12, 3012 Bern, Switzerland \\ Correspondence to: U. Lombardo (lombardo@giub.unibe.ch) \\ Received: 5 June 2014 - Published in Earth Surf. Dynam. Discuss.: 11 July 2014 \\ Revised: 12 November 2014 - Accepted: 24 November 2014 - Published: 16 December 2014
}

\begin{abstract}
The paper examines the role of neotectonic activity in the evolution of the landscape in southern Amazonia during the Holocene. It uses both new and published data based on the analysis of remote sensing imagery and extensive field work in the Llanos de Moxos, Bolivian Amazon. The study of the region's modern and palaeorivers, ria lakes, palaeosols and topography provides a strong case in favour of the thesis that the northern part of the Llanos de Moxos constitutes the southern margin of the Fitzcarrald Arch and that it has experienced uplift during the Holocene. The paper assesses the extent and timing of the neotectonic activity in light of the new data and reconstructs the evolution of the landscape since the late Pleistocene. The evidence suggests that at least two uplift events took place: a first uplift in the late Pleistocene, which caused the formation of Lake Oceano, and a second uplift during the mid-Holocene, which formed Lake Rogaguado. These two uplifts appear to be linked to the knickpoints observed close to the towns of Guayaramerín and Puerto Siles respectively. The backwater effect due to these uplifts transformed the region's major rivers in seasonal ria lakes, causing the deposition of thick organic clay layers along the Beni, Mamoré and Madre de Dios river banks. I argue that neotectonic episodes could have dramatically changed the drainage of the Llanos de Moxos, determining its flooding regime, soil properties and forest-savannah ecotone. These results stress the need for geomorphologists, palaeo-ecologists and archaeologists to take into account neotectonics when reconstructing the region's past.
\end{abstract}

\section{Introduction}

Palaeo-ecological reconstructions are a fundamental step in order to understand the origins of modern landscapes and the potential changes they could undergo due to climate change. Understanding how a particular region or ecosystem responded to past human disturbances and changes in past climate can tell us much about its resilience (Tinner and Ammann, 2005; Bush and Silman, 2007; Dearing, 2008). At the same time, understanding the processes behind the formation of modern landscapes and ecosystems can help assess to what extent these are "natural" or anthropogenic, eventually contributing to better informed conservation policies (Angermeier, 2000; Willis and Birks, 2006; Vegas-Vilarrúbia et al., 2011). These considerations are particularly true for the Llanos de Moxos (LM) (Fig. 1), which cover most of the savannah of southern Amazonia. Since the beginning of the Holocene this region has experienced both climate and human induced environmental changes (Mayle et al., 2000; Whitney et al., 2011; Urrego et al., 2013; Lombardo et al., 2013a, b).

The LM, located between the central Andes and the Brazilian Shield, is one of the largest seasonally flooded savannahs of South America. This region covers most of the southern part of the Amazon Basin and represents about $10 \%$ of the wetlands of South America (Junk, 2013). The forest-savannah ecotone is largely determined by seasonal floods (Mayle et al., 2007). The patchwork of savannahs and forests that covers the LM is a key element for the survival of its rich biodiversity, including rare and threatened species (Herzog et al., 2012; Wallace et al., 2013). The recent designation of three new protected areas has made the LM the world's largest Ramsar site (http://www.worldwildlife.org/press-releases/ bolivia-designates-world-s-largest-protected-wetland). In addition to its biodiversity, the LM is also of great palaeo- 


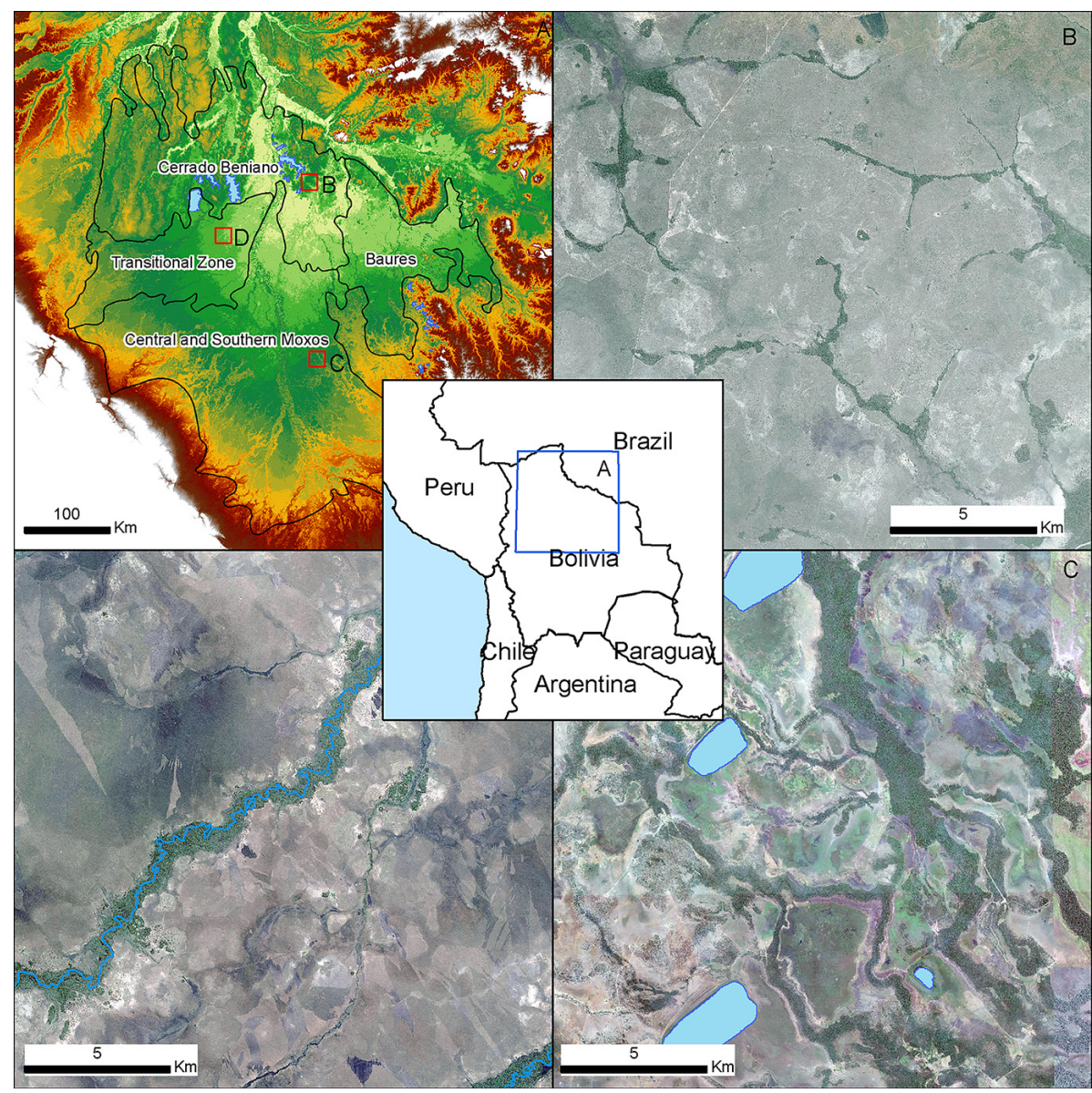

Figure 1. Geoecological subregions of the LM. (a) Map of the LM's subregions (based on Langstroth, 2011). (b) Satellite image of the Cerrado Beniano, a hilly landscape where forests grow in depressions. (c) Satellite image of the central and southern Moxos, a flat landscape where forests grow on elevated fluvial levees. (d) Satellite image of the transitional zone, where forests are relegated to the floodplains of underfit rivers.

ecological importance, as this region constitutes the southern border of the Amazonian rainforest, hence a preferential area to study past forest-savannah dynamics (Mayle et al., 2000). Inundation patterns, or flood pulses, have important effects on the biogeochemistry and the ecology of floodplain ecosystems, as they determine the occurrence and distribution of plants and animals, they affect primary and secondary production and influence decomposition and nutrient cycles in water and soils (Junk et al., 1989; Junk, 2013). Nowadays, the LM is constituted by different ecoregions which are characterized by specific vegetation assemblages which depend on the interplay between precipitation, drainage and soils (Navarro, 2011).

Recent research shows that the LM was first inhabited by hunter-gatherers at the beginning of the Holocene (Lombardo et al., 2013b). Its landscape has since then been significantly changed during the late Holocene by the so-called "Earthmover" societies, who built an extensive array of earthworks (Erickson, 2008; Mann, 2008; Lombardo and Prümers, 2010; Lombardo et al., 2011b). We know very little about the way early hunter-gatherers dealt with the seasonal floods during the early to mid-Holocene, but evidence suggests that they had to abandon the LM around $4000 \mathrm{yr}$ BP (before present) because of a large-scale environmental change, which also caused the burial of the early archaeological sites with fluvial sediments (Lombardo et al., 2013b). Inundation patterns also played an important role in shaping the way in which the late Holocene "Earthmovers" adapted to their local environment and reshaped the landscape, determining the spatial distribution of different earthworks (Lombardo et al., 2011b); especially in order to improve the drainage of agricultural land (Lombardo et al., 2011a, 2012).

Therefore, the reconstruction of past environments, landscapes and human-environment interactions in southern Amazonia throughout the Holocene greatly depends on our ability to reconstruct past inundation patterns.

Up to now, with the exception of a recent study which reconstructs $6 \mathrm{kyr}$ of palaeovegetation in the Baures subregion (Fig. 1) (Carson et al., 2014), palaeo-ecological reconstructions in the Bolivian Amazon have been mostly based 
on pollen and charcoal archives from lakes located outside the margins of the LM (Mayle et al., 2000; Burbridge et al., 2004; Whitney et al., 2011; Urrego et al., 2013). These archives have been interpreted as the result of changes in climate and pre-Columbian human impacts, implicitly assuming that other factors, such as neotectonics, did not play an important role in the evolution of the landscape during the Holocene. However, several authors have stressed that the LM shows manifold evidence of neotectonic activity during this period (Hanagarth, 1993). In particular, the existence of hundreds of rectangular and oriented lakes have been attributed to the propagation to the surface of bedrock faults (Plafker, 1964, 1974; Allenby, 1988); the formation of ria lakes in the northern part of the LM and the changes in the meandering behaviour of the Mamoré River at Puerto Siles have been associated with uplift and tilting movements in the northern LM (Hanagarth, 1993; Dumont and Fournier, 1994) and the counter clockwise movement of the Beni and Grande rivers has been associated with the tilting of the basement (Dumont and Fournier, 1994; Dumont, 1996). A ria lake forms when the lower part of a tributary is ponded at the margin of the trunk river because of a quick depositional event of the main river, a raise of the base level due to faulting or tilting, or because of regional subsidence (Schumm et al., 2002).

These studies suggest that neotectonics had a significant impact on the formation of the modern landscape of the LM and, hence, on past inundation patters. However, because of the lack of chronological data, digital elevation models (DEMs), remote sensing imagery, and the difficulty of performing fieldwork in the region at the time of these early studies, published work to date does not provide quantitative measures of the neotectonic movements and do not define a chronological framework for the tectonic activity. Furthermore, previous observations based on remote sensing imagery have not been corroborated by field evidence. The extent and the chronology of neotectonic activity are extremely important in order to assess the potential impact that neotectonics could have had on the evolution of southern Amazonia. Neotectonics could have brought about changes in the drainage of the LM during the Holocene which, in turn, could have altered the flooding regime, vegetation assemblages, landscape evolution, and human-environment interactions in the region.

In the present paper, previous studies are revisited in light of new remote sensing imagery, digital elevation models and extensive field work. Based on this evidence, I propose a general framework to explain the contribution of neotectonics to the evolution of the landscape and inundations patterns in southern Amazonia. The paper describes the physical setting of the LM and the geomorphological evidence that supports the existence of neotectonic activity. The paper is organized in three main sections. The first part, Sect. 2, describes the study area, focusing on three aspects: the general landscape, the modern flooding patterns and the geology. The second part, Sect. 4, assesses the evidence of neotectonic activity. This is subdivided into two parts: rivers/palaeorivers and lakes. Here, the first paragraphs review the existing literature; the following paragraphs present new data and the results of the study. The third part, Sect. 5, addresses the following questions:

1. What could be the general mechanism behind neotectonics in southern Amazonia?

2. What was the extent and timing of neotectonic activity?

3. How did neotectonics affect the LM hydrology during the Holocene?

\section{The study area}

\subsection{The LM and its subregions}

The LM, in southern Amazonia, is a large seasonally flooded savannah criss-crossed by strips of forest. However, important differences exist between its subregions (Fig. 1). The northern LM, also called Cerrado Beniano, is covered by reddish, relatively well drained lateritic crusts, which host Cerrado-like savannahs (Langstroth, 2011; Navarro, 2011). Forests grow in the lower part of the landscape, mostly in the small valleys between lateritic hills where sediment accumulation provides enough humidity and room for tree roots to grow (Fig. 1b). Compared to the rest of the LM, which are almost totally flat, this region is hillier and shows noticeable topographic changes. As it can be seen in the DEM in Fig. 1a, most of the Cerrado Beniano is well above the level of the seasonal floods. Hence, here, the forest-savannah ecotone is determined primarily by soil properties and local precipitation, and is relatively independent from the LM's flood regime. Some of the largest lakes in the LM are located here.

In the central and southern LM (Fig. 1c) the topographic control on the savannah-forest assemblage is inverted with respect to the northern LM, in that forested areas tend to be concentrated on high ground rather than valleys. The central and southern parts of the LM are an extremely flat floodplain, mostly covered by seasonally flooded savannahs, which, in general, are fluvial backswamps. Savannahs are interspersed by strips of forests, which mainly grow on the fluvial deposits that remain above the level of the seasonal floods (Mayle et al., 2007). Most of the soils are relatively fertile because they generally form on recently deposited, clay-rich, Andean sediments. The most common soil types are Gleysols in the savannahs, Fluvisols in the recent fluvial levees and Luvisols and Cambisols in the older palaeolevees (Langstroth, 1996; Boixadera et al., 2003; Lombardo et al., 2014). Here soil properties and the forest-savannah ecotone along fluvial splays and levees are primarily determined by the inundation patterns. This is the part of the LM where hundreds of rectangular and oriented lakes formed. 
In the western LM, the Cerrado Beniano is separated from the central LM by a transitional zone (Fig. 1d). This encompasses the savannahs north and west of Santa Ana de Yacuma. This area is very flat and crossed by underfit rivers. These rivers flow on ancient courses of the Beni River (Dumont and Fournier, 1994) and do not overflow during the rainy season (Walker, 2004). The savannah is seasonally flooded, but floods are caused by local precipitation alone, with no contribution from river overflow. The lack of fluvial sediment deposition, combined with strong redoximorphic conditions, results in highly hydromorphic soils, very poor in nutrients, often with very low $\mathrm{pH}$ values and toxic levels of exchangeable aluminium (Navarro, 2011; Lombardo et al., 2013a).

The northeastern part of the LM, the Baures subregion, is characterized by a very poorly drained savannah dotted with several forested areas. These forests grow on 2-3 m high elevated platforms that constitute outcrops of tertiary rocks (Pitfield and Power, 1987) (Fig. 2b). This is the less accessible and therefore less studied area of the LM.

With an average slope of $0.014 \%$, the LM is extremely flat and subject to seasonal floods. Seasonal floods and backswamp sedimentation along the basins of the Mamoré and Beni rivers are primarily controlled by El Niño/La Niña cycles (Aalto et al., 2003) and the South Atlantic sea surface temperature anomalies (Ronchail et al., 2005).

Precipitation in the LM range from 1350 to $2450 \mathrm{~mm} \mathrm{yr}^{-1}$ (yearly average precipitation between 1971 and 2000 at Trinidad; Ronchail and Gallaire, 2006), while the flooded area is in the range of $30000-92000 \mathrm{~km}^{2}$ (Hamilton et al., 2004; Melack and Hess, 2011). This shows the high sensitivity of the LM and its flooding regime to relatively small changes in precipitation. Flood dynamics are also influenced by the Mamore River, which is the base level for most of the rivers in the region (Bourrel and Pouilly, 2004). The duration and extent of the inundations depend on the combination of precipitation in the upper catchment of the Mamoré River, the impeded drainage of local precipitation (Bourrel et al., 2009) and the elevation of the water table (Ronchail et al., 2005; Fan et al., 2013). A lag of 1-3 months is observed between the time of maximum precipitation in the upper catchment of the Mamoré and the peak in floodplain inundation (Hamilton et al., 2004). This results from the movement of river runoff from upland catchments to the floodplains, as well as from the delay in the drainage of inundated areas to the rivers (Hamilton et al., 2004). On an interannual basis, consecutive years with large inundations are caused by groundwater storage (Ronchail et al., 2005).

\subsection{The geology of the Llanos de Moxos}

The Andes-Amazon foreland basin system is not a typical foreland basin system (DeCelles and Giles, 1996); it is divided into two different basins by the uplifting Fitzcarrald Arch, a $600 \mathrm{~m}$ high bulge (Espurt et al., 2007, 2010). It has been hypothesized that the Fitzcarrald Arch is the projection to the surface of a buoyant flat slab resulting from the subduction of the Nazca Ridge (Espurt et al., 2008). The formation of the flat slab about $4 \mathrm{Myr}$ ago would have brought about the back-arc uplift of the Fitzcarrald Arch (Espurt et al., 2007, 2008; Regard et al., 2009). The LM constitutes the foredeep of the southern Amazonian foreland basin. It is located between the central Andes, to the W-SW, and the Brazilian Shield, to the E. The Brazilian Shield dips gently towards the Andes underlying unconsolidated sediments (Plafker, 1964; Hanagarth, 1993). Very little is known about the stratigraphy and thickness of these foreland deposits. Geophysical surveys in the southern part of the LM indicate the presence of thick layers of fluvial sediments covering the Brazilian Shield (Plafker, 1964). The sediments overlying the crystalline bedrock thicken gradually from the margin of the Brazilian Shield towards the west. The thickness of the sediments is more than $5500 \mathrm{~m}$ near the Andean foothills and approximately $800 \mathrm{~m}$ at a distance of $150 \mathrm{~km}$ from the Andes, in the village of Perú (Plafker, 1964) (Fig. 2b). In the northern part of the LM, recent surveys have shown the presence of metamorphic rock at $165 \mathrm{~m}$ below Santa Ana de Yacuma and at $65 \mathrm{~m}$ below the town of Magdalena (UNASBVI-JICA, 2009). A $200 \mathrm{~m}$ long and $50 \mathrm{~m}$ high rocky exposure, belonging to the Brazilian Shield, outcrops in the location of El Cerro, $60 \mathrm{~km}$ north of Santa Ana de Yacuma. Several authors have identified an uplifting region in northern Beni; the so-called Linea Bala-Rogaguado in Fig. 2b (Allenby, 1988; Dumont, 1996; Dumont and Fournier, 1994; Plafker, 1964; Hanagarth, 1993). The Linea Bala-Rogaguado, also called Reyes-Puerto Siles axis (Dumont, 1996), has been interpreted as a SW-NE faulting system which represent the south-western extension of the Tapajó fault in central Brazil (Dumont and Fournier, 1994). More recently, it has been proposed that the Puerto Siles uplift is part of the SE-NW oriented Andean forebulge axis (Aalto et al., 2003; Roddaz et al., 2006) (Fig. 2b).

\section{Methods}

The study examines the evidence of neotectonic activity in southern Amazonia and its impact on flooding patterns and landscape evolution during the Holocene. It focuses on the analysis of modern and palaeorivers, ria lakes, palaeosols and landscape topography. For this it combines the analysis of remote sensing images, extensive fieldwork in the LM and a review of existing studies. ArcGis 10.1 has been used to produce the topographic maps shown in Figs. 1a, 2, 3a, 6a and 9 and the topographic profiles shown in Figs. 5, 6a and 10; these are based on the hole-filled Shuttle Radar Topography Mission (SRTM) imagery, where elevation values for water bodies are interpolated (Jarvis et al., 2008). Images of landscape features used in Figs. 1b-d, 3b-d, 7a and 10b are retrieved from Google Earth. Images used in Figs. 4 and 10a 


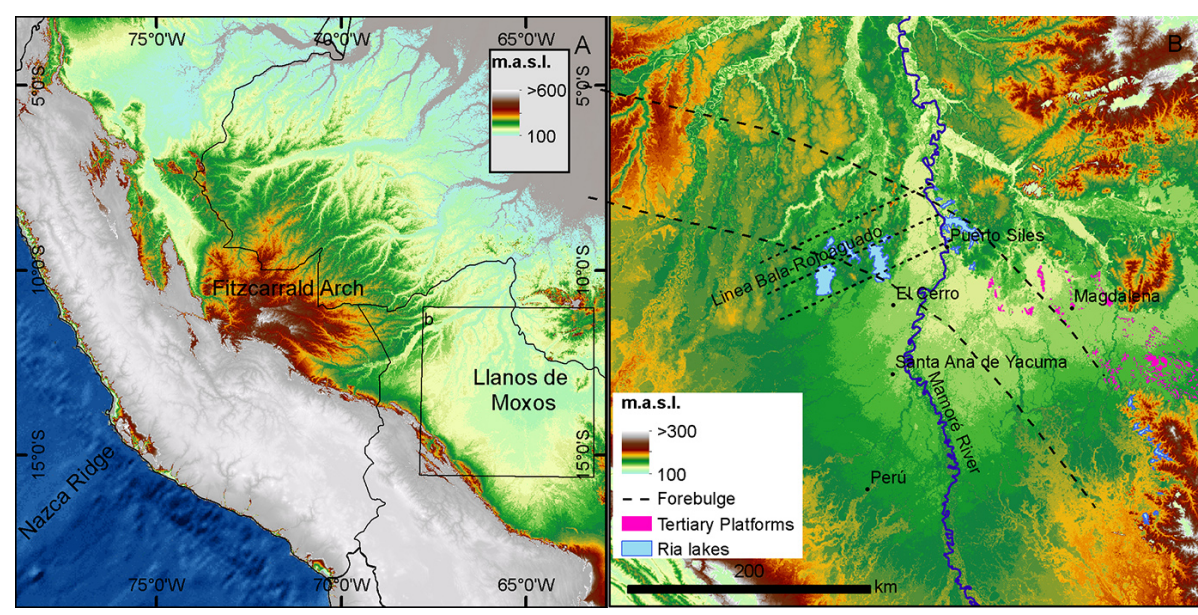

Figure 2. Geological setting of the LM. (a) Topographic map of central western South America showing how the south-eastern part of the Fitzcarrald Arch constitutes the LM's north-western border. This, together with the Brazilian Shield in the north-east, forms a continuous barrier which impedes the drainage of the LM. (b) Topographic map of the LM showing the location of the Linea Bala-Rogaguado (as in Dumont and Fournier, 1994) and the Andean forebulge (as proposed by Aalto et al., 2003).

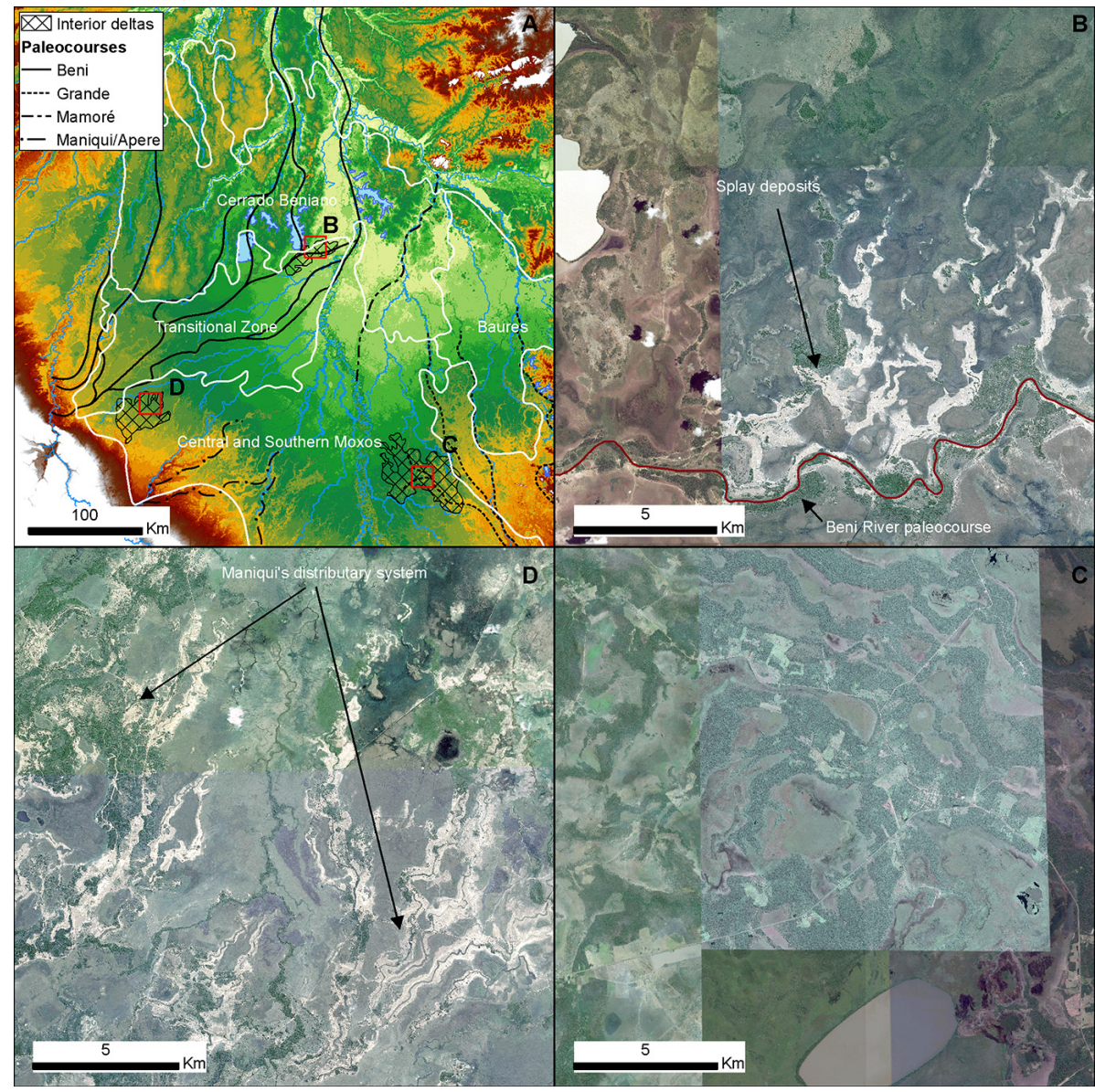

Figure 3. Map of rivers and palaeorivers in the LM. (b) An example of crevasse splays at the distal part of a palaeocourse of the Beni River. (c, d) Interior deltas formed by repeated avulsions of the Grande and Maniqui rivers, respectively. 


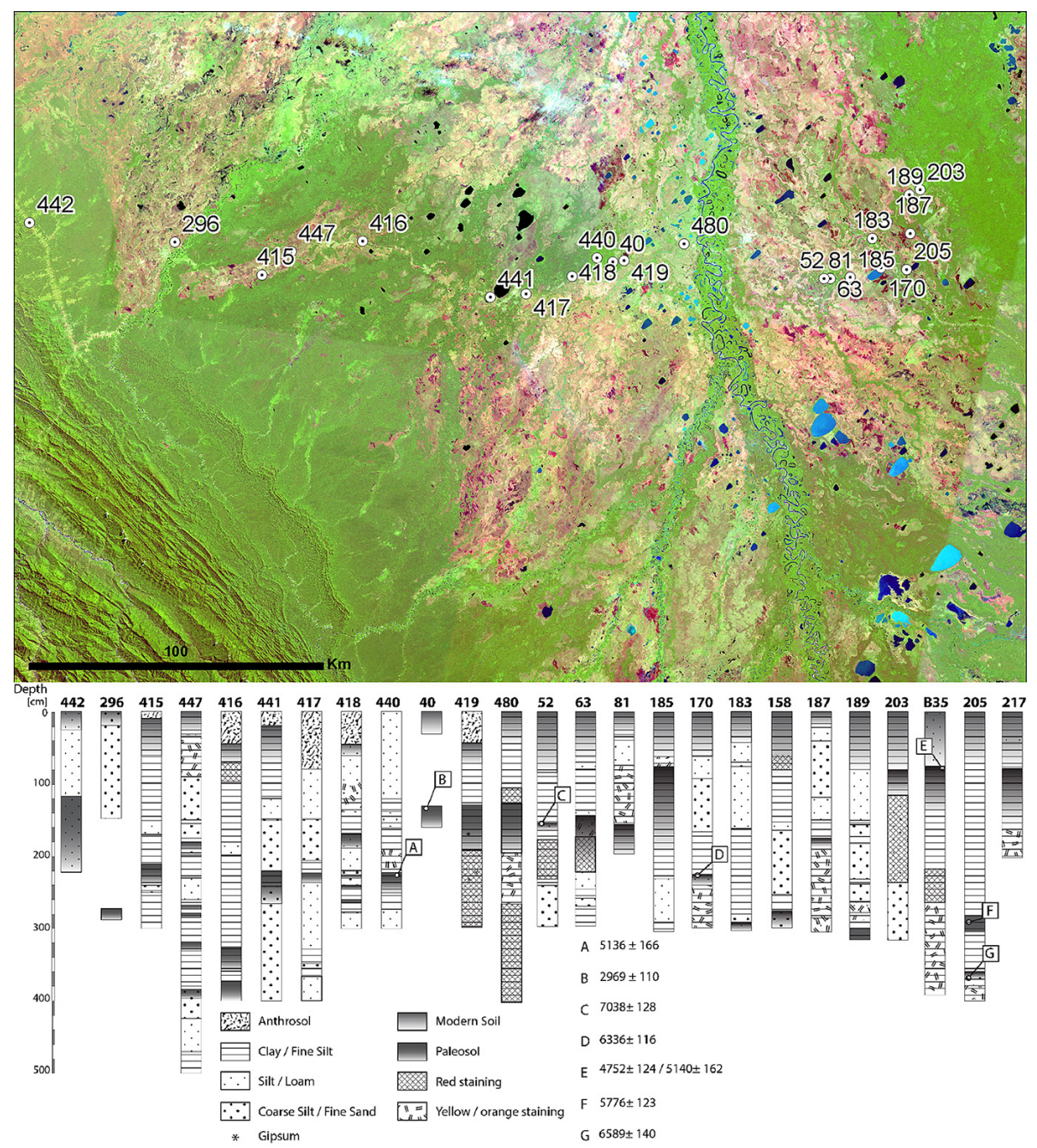

Figure 4. Cored profiles along a $300 \mathrm{~km}$ long transect crossing the central and southern LM. Palaeosols are always found below alluvia. Sequences of several organic horizons separated by alluvial deposits (for example core 447) indicate frequent avulsions. Radiocarbon ages indicate that the central and southern LM were covered with fluvial sediments during the mid- to late Holocene. AMS (applied mass spectrometry) radiocarbon ages of palaeosols in profile 40 (uncalibrated age $2900 \pm 35 \mathrm{yr} \mathrm{BP}$ ) and 440 (uncalibrated age $4520 \pm 40 \mathrm{yr}$ BP) were measured at the Poznan Radiocarbon Laboratory. The rest of the radiocarbon ages have been taken from Lombardo et al. (2012).

are Landsat ETM (Enhanced Thematic Mapper) and have been downloaded from GLOVIS (http://glovis.usgs.gov/). The Mamoré River has been manually digitalized over the hole-filled SRTM. Elevation points within the Mamoré River channel have been extracted from the hole-filled SRTM at each vertex of the digitalized line and plotted against distance downstream (Fig. 5b) and against their latitude (Fig. 5a, c). The latter facilitates the direct comparison between the slope and the morphology of the river. River reaches have been identified on the basis of the remote sensing imagery and after a visual analysis of the river geometry and slope. The average slope of each reach is represented as a line (Fig. 5a, c). Sinuosity was measured for each river reach (19 in Fig. 5) as the river length divided by the valley length. In order to investigate the origin and time of formation of
Lake Rogaguado, the lake has been cored in four places; however, only the data from two of the cores is presented in this paper, cores 398 and 397, as the other two cores did not reach the bottom of the lacustrine sediments. Lake cores have been taken with a gravimetric corer. In order to reach the sediments below the lacustrine phase, location 398 has been cored deeper using a Livingstone corer. The radiocarbon age from the base of the lacustrine phase of core 378 comes from a fragment of wood; it has been calibrated with Calib 7.0 (http://calib.qub.ac.uk/calib/calib.html) using the SHcal13 calibration curve (Hogg et al., 2013). In order to assess the sedimentary regime across the central and southern LM, a stratigraphic transect has been made from the Andes to the eastern LM (Fig. 4). Stratigraphic cores along this transect have been taken with a Waker motor vibracorer and 
described in the field. The description and radiocarbon ages of the cores taken east of the Mamoré River are based on Lombardo et al. (2012).

\section{The evidence of neotectonic activity in southern Amazonia}

\subsection{Rivers and palaeorivers}

Tropical alluvial rivers can change in response to different factors, notably changes in climate, neotectonics or their intrinsic evolution over time (Schumm et al., 2002; Bridge, 2009; Burbank and Anderson, 2011; Gupta, 2011). In particular, river avulsions take place when the main channel becomes infilled with sediments, triggering the diversion of the river into a new course (Slingerland and Smith, 2004; Buehler et al., 2011). River avulsions are the main mechanism behind the formation of distributary fluvial systems (DFS), which fill alluvial basins (Hajek and Edmonds, 2014; Weissmann et al., 2010; Hartley et al., 2010). High aggradation rates in the main river channel can result from a variety of causes such as (i) an increase in the sedimentary load of the river; (ii) an increase in the peak water discharge of the river or (iii) a decrease in the channel gradient, which can be caused by a rise of the base level or downstream tectonic uplift (Slingerland and Smith, 2004). Therefore, the interpretation of environmental and palaeo-environmental fluvial forms and palaeoforms is not always straightforward. Avulsive processes and the formation of DFS within the LM have been described in the case of the Beni River (Plafker, 1964, 1974; Hanagarth, 1993; Dumont, 1996; Hartley et al., 2010) the Grande River (Hanagarth, 1993; Dumont, 1996; Lombardo et al., 2012; Plotzki, 2013) and the Mamoré River (Plotzki et al., 2011, 2013) (Fig. 3a) but the mechanisms behind these avulsions are controversial. The northward migration of the Beni River deflection point has been associated with a fault connected to the Andean foothill margin (Dumont, 1996; Plafker, 1964; Hanagarth, 1993; Allenby, 1988). Based on the assumption that the Grande River changed its course following a counter clockwise movement, the tilting of the basement, and the consequent uplift of its southeastern margin, has been considered responsible for its avulsions (Hanagarth, 1993; Dumont, 1996). More recently, however, it has been suggested that the megafan of Grande River did not follow a counter clockwise movement (Plotzki, 2013). The study of an interior delta/sedimentary lobe at the distal part of one of the Grande River palaeocourses, seems to indicate that the Grande River avulsive phase may have been triggered by an increase in river discharge or sedimentary load that could have been brought about by a mid- to late Holocene climate shift towards wetter conditions (Lombardo et al., 2012; Plotzki et al., 2013). Similarly, the avulsion of the Mamore seems to be related to an increase in discharge probably caused by a change in climate (Plotzki et al., 2013). The interior delta formed by the Maniqui River (Fig. 3d) has

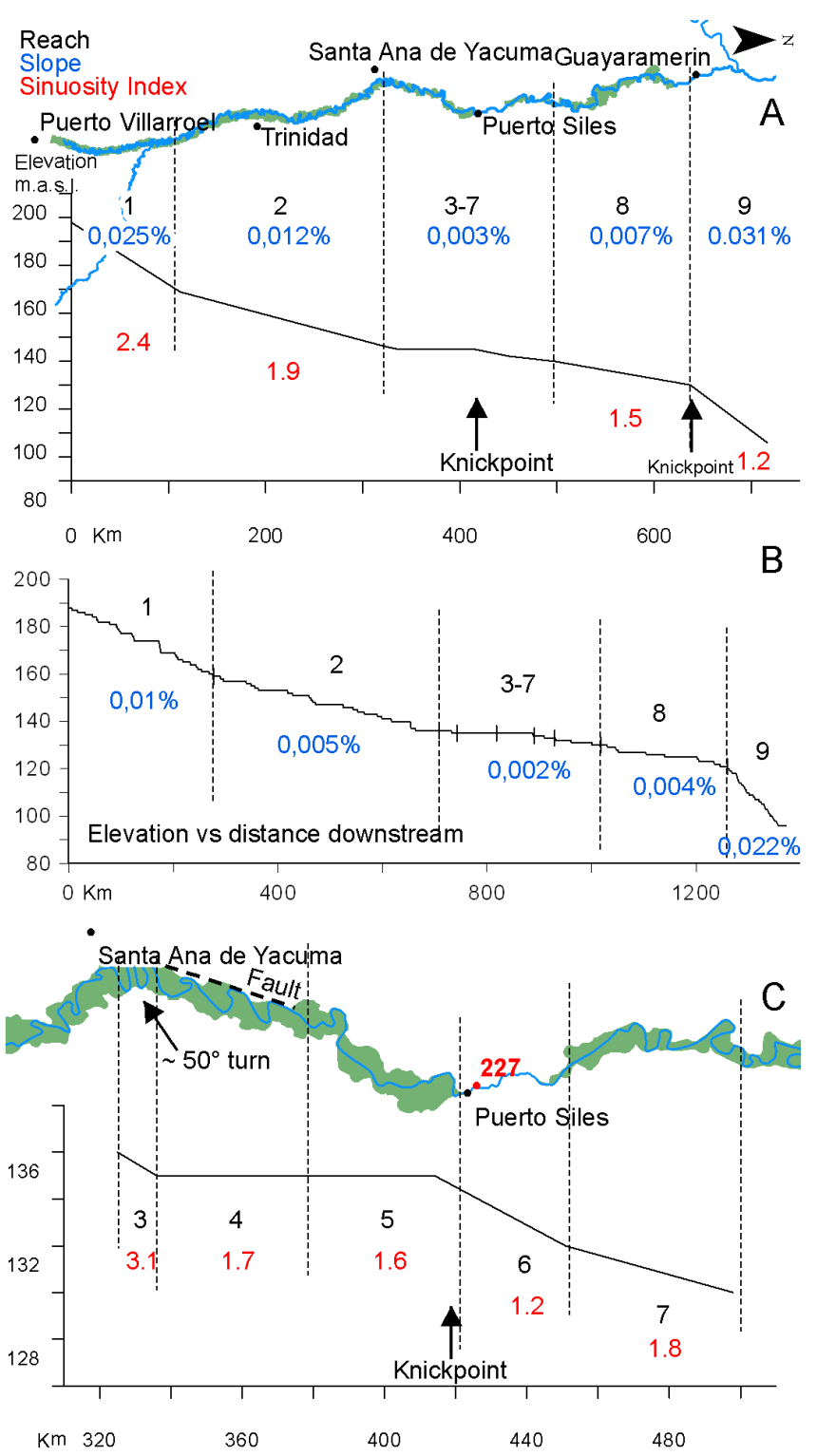

Figure 5. Geometric characteristics of the Mamoré River. (a) Valley river slope and sinuosity index (SI) of the Mamoré between Puerto Villarroel and Guayaramerín are plotted against each other. Here, the valley slope changes twice, indicating the presence of knickpoints: one in Puerto Siles and the other one close to Guayaramerín. (b) The slope is plotted against river length, showing the same pattern as in (a). In (c), a more detailed map of the section between Santa Ana de Yacuma and $100 \mathrm{~km}$ downstream of Puerto Siles shows a series of compressed meanders at Santa Ana, followed by a $50^{\circ}$ turn and three asymmetric meanders. After Puerto Siles, the SI declines abruptly and the gallery forest disappears. Point 227 is where photos (c) and (b) in Fig. 7 were taken. 


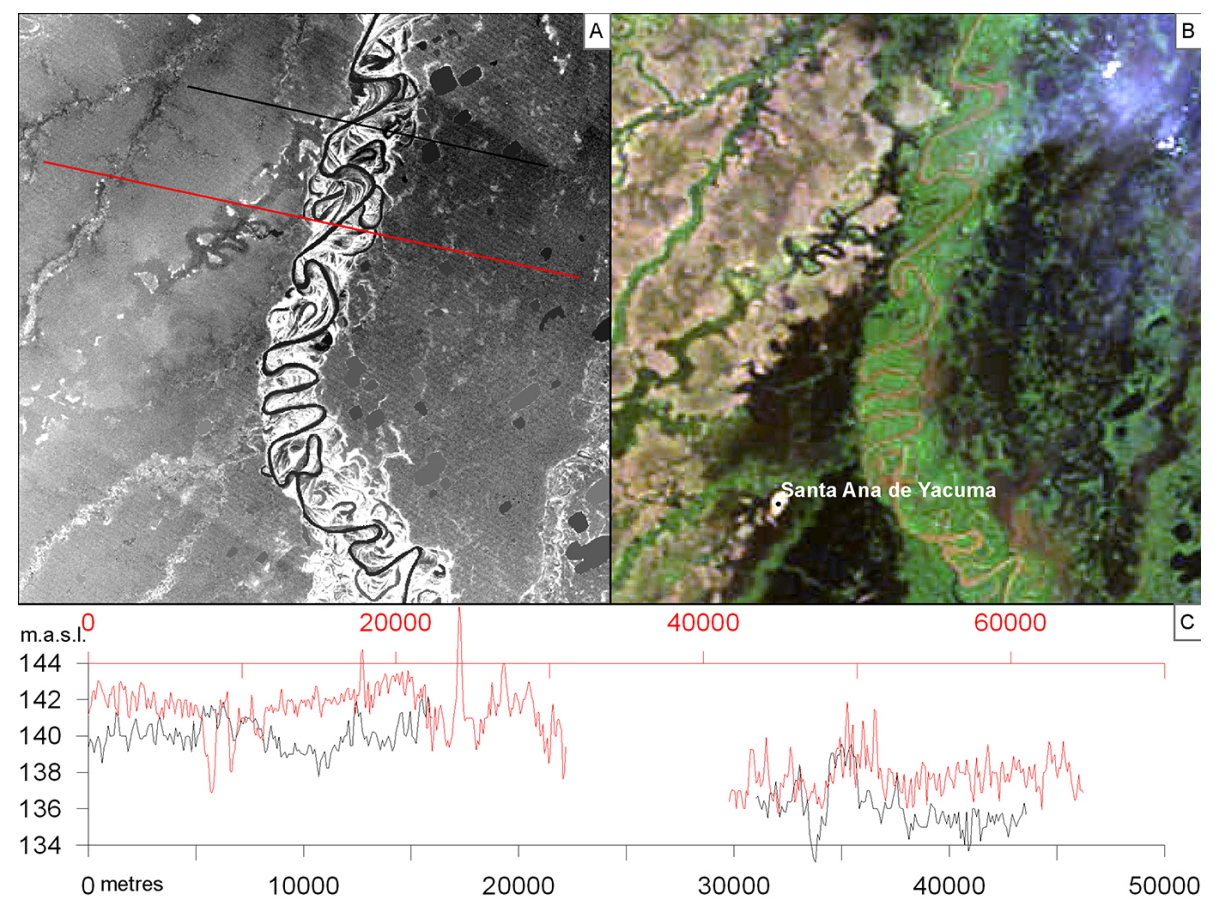

Figure 6. (b) Location of the topographic profiles shown in (c). (b) MODIS image of the flooded areas around Santa Ana de Yacuma in 2007 (black areas). (c) Topographic profiles across the asymmetric meanders of reach 4 (Fig. 5c), indicating that the western side of the river (the dry area shown in b) is about $5 \mathrm{~m}$ above the level of the eastern side of the Mamoré. This further supports the hypothesis of the presence of an active fault as indicated in Fig. $5 \mathrm{c}$.

been described by Hanagart and Sarmiento (1990); they observed that the formation of the Maniqui megafan was caused by a reduction in the slope, which induced frequent avulsions.

A situation similar to that of the Maniqui and Grande river deltas (Fig. 3c) is found in the distal part of a palaeocourse of the Beni River (Fig. 3b), where numerous crevasse splays formed. Although these fluvial forms have received little attention in the literature, their location on the southern border of the Cerrado Beniano (the Beni crevasse splays) and the transitional zone (the Maniqui River megafan), suggests that their formation could respond to a change in slope, as suggested by Hanagart and Sarmiento (1990) for the Maniqui, which was probably caused by a downstream uplift.

The central and southern Llanos de Moxos are covered by many palaeolevees belonging to DFS. This is characteristic of actively subsiding basins (Hartley et al., 2010; Latrubesse et al., 2010; Weissmann et al., 2010, 2013; Rossetti et al., 2012). In order to study these DFS, 25 stratigraphic cores were retrieved along a $300 \mathrm{~km}$ line crossing the central LM (Fig. 4). All the profiles reveal intercalations of clays, loams, silts, fine sands and organic-rich palaeosols. The association of levee sands and silts, splay sands, backwater loams and (organic) clays is characteristic of an avulsive fluvial setting, which is consistent with the formation of megafans in subsiding basins. Radiocarbon dating of palaeosols found below these alluvia indicate depo- sition during the mid- to late Holocene (Fig. 4). Data from drilling reported in Plafker (1964) reveal that this assemblage of Holocene fluvial sediments is similar to the rest of Quaternary and possibly Tertiary sediments constituting the $800 \mathrm{~m}$ of basinal infilling at the site of Perú. Although the evolution of specific rivers at any given time could have been influenced by different factors, the general landscape of the central and southern Llanos de Moxos is that of a typical subsiding basin.

However, there are characteristic features in river patterns that can be associated with neotectonic activity more clearly than avulsive processes. The existence of underlying active tectonic processes can be noted from the analysis of features such as changes in the meandering pattern and the presence of knickpoints (Schumm et al., 2002; Burbank and Anderson, 2011). Evidence of neotectonic activity in the LM can be inferred from the analysis of the Mamoré River. The sharp reduction in the sinuosity of the Mamore River north of Puerto Siles (Fig. 5) has been considered direct evidence of uplifting along the Linea Bala-Rogaguado (Dumont and Fournier, 1994). The existence of this uplift is consistent with the presence of several rapids located downstream of Puerto Siles (Dumont and Fournier, 1994). In the lower part of the Mamore and the Beni rivers, rapids are caused by the outcropping of pre-Cambrian rocks belonging to the Brazilian Shield (Hanagarth, 1993). 


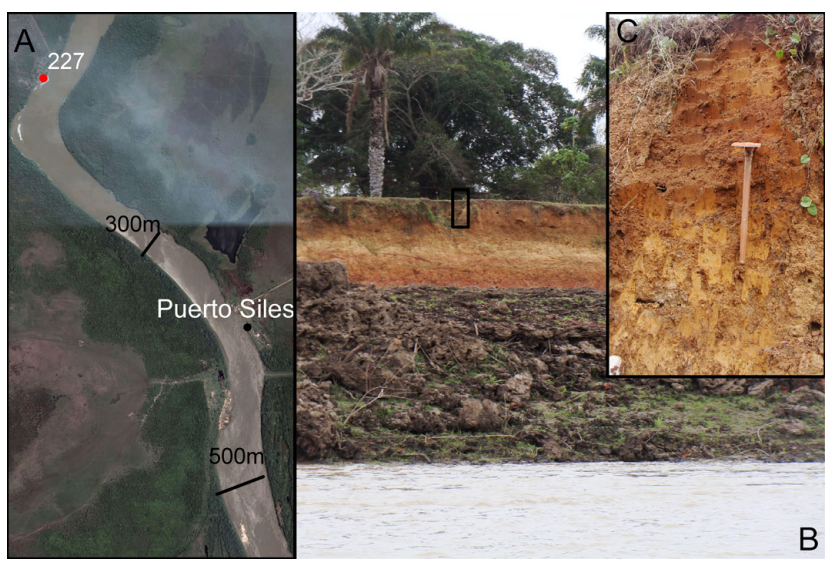

Figure 7. Changes in the geomorphic features of the Mamoré River at Puerto Siles. (a) Google Earth image showing the change in Mamoré's width and the outcropping of lateritic crusts; (b) The Mamoré River bank at point 227: a lateritic crust covered by old fluvial sediments; (c) Photograph of a well developed Luvisol at the top of the fluvial levee at location 227.

The presence of the Puerto Siles uplift is corroborated in this study by the analysis of the SRTM imagery (Fig. 5). The analysis of the topographic profile of the Mamore River shows several changes along its course. In its first $400 \mathrm{~km}$ (reaches 1-5 in Fig. 5) the Mamoré River behaves as a free meandering river, with its slope and sinuosity decreasing downstream. This behaviour is interrupted at Puerto Siles, where the lowest sinuosity value is associated with a clear increase in slope and to the appearance of lateritic crusts within the river channel, causing the formation of rapids. The change experienced by the Mamoré River at Puerto Siles is also noted in the river's topography, which goes from concave to convex at this point. This change in Puerto Siles is preceded by three compressed meanders followed by three asymmetric meanders (reaches 3 and 4 in Fig. 5). A clear change in the direction of the river, with a clockwise turn of about $50^{\circ}$, is associated with the compressed meanders. Compressed meanders indicate a downstream increase of the river bank's resistance to erosion, often the result of the appearance of bedrock in the channel following localized uplift (Holbrook and Schumm, 1999). This situation is similar to what can be seen in the rest of the Amazon Basin, where discharge characteristics and bank stability play an important role in channel pattern variations (Baker, 1977). The topographic profiles across reach 4 of the Mamore River show that the western side of the river is about $5 \mathrm{~m}$ higher than the eastern side (Fig. 6a). This difference in elevation between the two sides dramatically affects the flooding regime; the savannah in the north of Santa Ana de Yacuma (the transitional zone) is hardly ever flooded by the Mamoré outflow, whilst the savannah in the eastern side is severely flooded every year (Fig. 6b). Therefore, the asymmetric meanders and the $50^{\circ}$ change in direction can be interpreted as the result

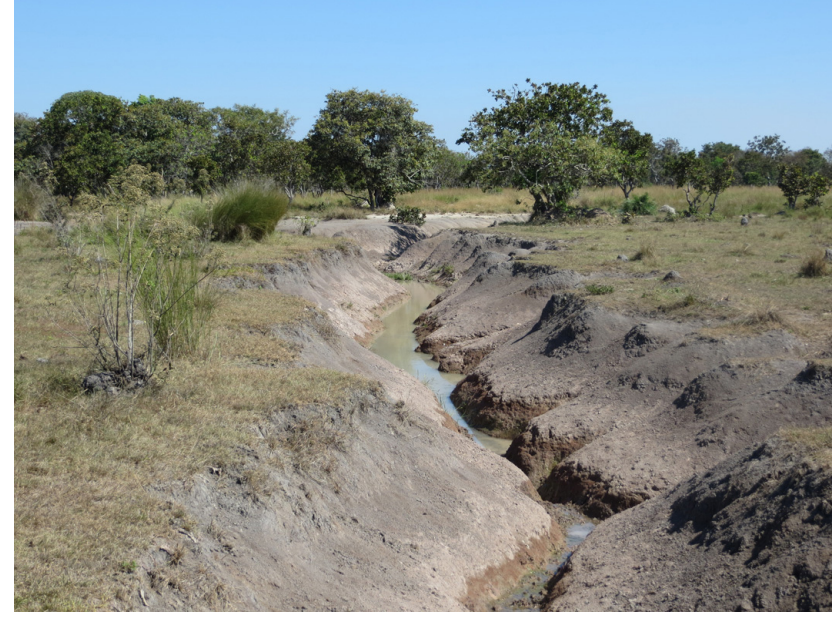

Figure 8. An erosional feature incising the savannahs of the transitional zone along the road from Santa Ana de Yacuma to lake Rogaguado (the dry area shown in Fig. 6b), indicating that these savannahs are established in uplands subject to erosion.

of a normal fault with its footwall on the western side of the river.

In addition, the presence of underfit rivers in the transitional zone suggests that this subregion is uplifting. This uplift is evident in the formation of a new drainage network constituted by small creeks, which are a common element of the landscape easily seen in the field. Figure 8 shows one of these erosive features, which are formed when rain water travels from the waterlogged savannah to the underfit rivers.

The topographic profile of the Mamore shows how, at Puerto Siles, the meander belt that borders the river for the first $400 \mathrm{~km}$ is replaced by two irregular forested levees. No oxbows are present here. A $40 \%$ decrease in the channel's width is also observed here. The changes at Puerto Siles suggest that the Mamoré experiments acceleration and deepening of the channel. These changes increase the capacity of the river to transport sediment and, in turn, this changes its behaviour: from depositing sediments it now begins to erode its bed. A further confirmation of this change is that downstream from Puerto Siles the Mamoré's river banks are made by thick lateritic crusts covered by old fluvial levees, with no sign of recent fluvial deposition (Fig. 7b, c). Here, welldeveloped Luvisols are found on top of the levees. About $200 \mathrm{~km}$ downstream, close to Guayaramerín, a second knickpoint appears. After this second knickpoint, the Mamoré reaches its steepest slope (reach 9 in Fig. 5).

The analysis of the SRTM indicates that the general downslope topography of the LM is interrupted at Puerto Siles where the terrain becomes hillier. Despite the fact that these hills significantly change the slope of the LM, the river network seems to be unaffected by them. In fact, as we can see in the SRTM images shown in Fig. 9, all the rivers maintain their northward convergent path, cutting through these 


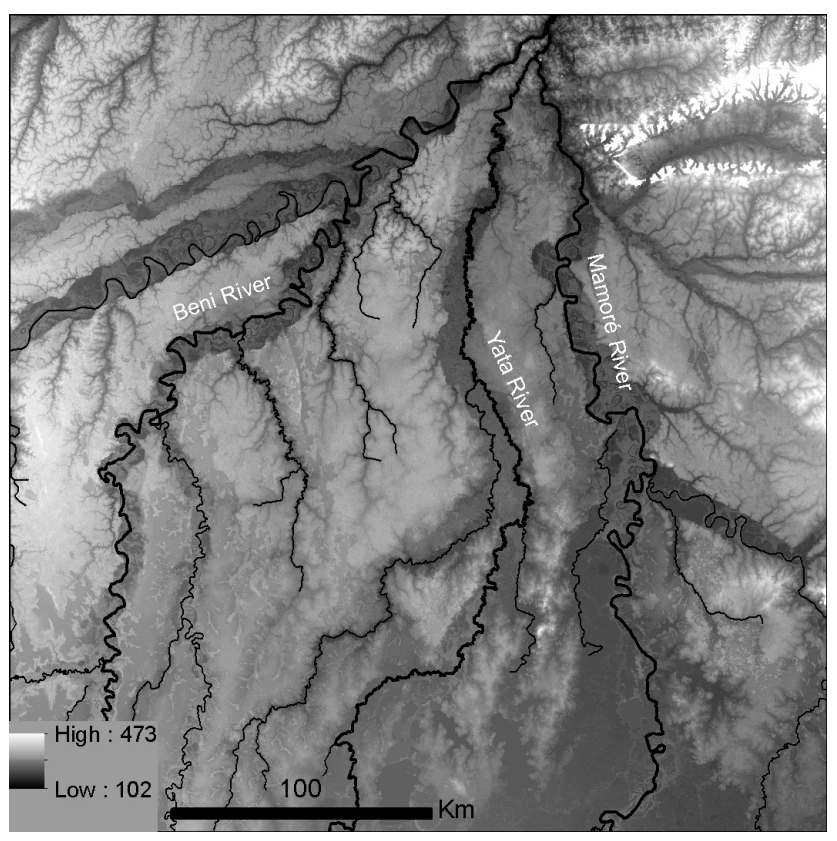

Figure 9. SRTM image showing an example of a river network in the Cerrado Beniano. All rivers flow north, against the slope of the general terrain, suggesting that the development of the drainage network preceded the uplift that crated the hilly landscape.

hills; no rivers flow south. This setting suggests that the courses of these rivers were established before the onset of the uplift, and that the rivers have overcome this obstacle by incising the uplifting rocks and sediments. This is consistent with the hypothesis that these hills constitute the southern margin of the Fitzcarrald Arch, which started uplifting about $4 \mathrm{M} \mathrm{yr}$ ago (Espurt et al., 2007). Not all the valleys crossing the uplifted area have been active at the same time, as shown by the palaeocourses of the Beni River: the Beni occupied at least two other valleys (now occupied by the Yata and Tapado rivers) before establishing its modern course (Dumont and Fournier, 1994).

\subsection{Lakes}

There are more than 800 lakes in the LM, most of which are rectangular and oriented. Until recently, the most accepted hypothesis behind the formation of these rectangular and oriented lakes of the LM has been tectonic (Plafker, 1964; Allenby, 1988). According to Plafker, the lakes' rectangular shapes results from the propagation of bedrock fractures through unconsolidated sediments and the sinking of basement blocks. However, the coring of three of these lakes has shown that tectonics cannot explain their formation, as a horizontal palaeosol is found at the same depth both outside and inside the lakes (Lombardo and Veit, 2014). Given the available data, the most likely mechanism behind the formation of the rectangular and oriented lakes seems to be the erosive action of waves on the lakes' shores due to constant winds
(Lombardo and Veit, 2014). Apart from the rectangular and oriented lakes, a second group of lakes, found mainly on the eastern and northern borders of the LM, are the ria lakes. Ria lakes are a valuable source of information to reconstruct past environments, sedimentary histories and tectonic processes (Behling et al., 2001; Irion et al., 2006, 2011). They resemble water reservoirs resulting from a dam, where a preexisting valley is flooded and transformed into a lake. In the Bolivian Amazon, ria lakes have been reported in the southeastern and in the northern parts of the LM. In the southeastern side they have been formed by the rapid deposition of sediments by the Grande River, which dammed fluvial valleys previously eroded in the Brazilian Shield (Dumont and Fournier, 1994). Ria lakes that have been described in the northern LM are connected to the Linea Bala-Rogaguado (Hanagarth, 1993; Dumont and Fournier, 1994). Here there are two types of lakes. The first type, which includes Lago Largo and Agua Clara (Fig. 10), is the typical ria lake which results from a valley flooded by damming; hence, similar to those formed by the former Grande River. The second type, such as Rogaguado and Ginebra, is constituted by lakes that have formed within a valley that became flooded because of tilting (Dumont and Guyot, 1993; Dumont and Fournier, 1994). Ria lakes of tectonic origin are not limited to the LM; they have also been described in the Marañon and Ucayali basins (Räsänen et al., 1987; Dumont, 1993). Many other ria lakes are found along the Negro, Xingú and Tapajó rivers in the Brazilian Amazonia. These seem to have formed because of the increased river incision caused by the drop of the ocean water level during the Last Glacial Maximum (Irion et al., 2011), but it has been suggested that tectonic movements could have also played a role. (Latrubesse and Franzinelli, 2002).

The counter clockwise shift of the Beni River (Dumont, 1996) has left several palaeofloodplains, one of which is nowadays occupied by Lake Rogaguado. If we assume that, before the formation of the lake, when the Beni River flowed through the Rogaguado Valley its slope was relatively constant, the northern uplift or tilting that generated the lake, would have, therefore, also changed the slope of the original valley. The measurement of this change could provide constraints on the extent of the tectonic movement. Figure 10 shows the the original slope of Rogaguado's floodplain and the amount of vertical movement which created the lake. In order to confirm the mechanism at the origin of these lakes and constrain the timing of their formation, Lake Rogaguado was cored at several locations. Figure 11 shows the two cores retrieved from Lake Rogaguado that reached the bottom of the lacustrine sediments. The bottom part of core 398 includes the terrestrial phase that preceded the formation of the lake. This is a palaeosol characterized by abundant red oxides at its base, indicating recurrent wet and dry periods. The amount of organic matter increases towards the top of the terrestrial phase, which probably corresponds to a fossil Ah horizon. This terrestrial phase seems to correspond 


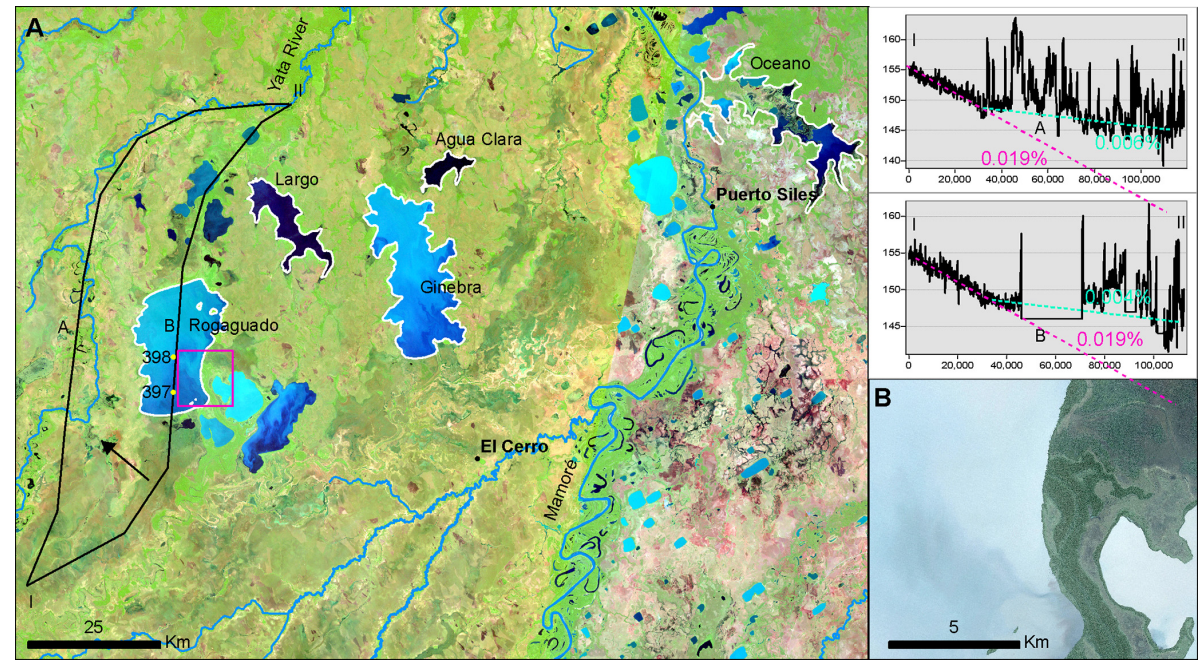

Figure 10. Landsat image of ria lakes in the Cerrado Beniano. (a) Yellow points in Lake Rogaguado indicate the location of the cores shown in Fig. 11. Topographic profiles from I to II show a reduction in the slope, coinciding with two $90^{\circ}$ turns of the Yata River (profile A) and the southern shore of Lake Rogaguado (profile B). The topographic profile B also shows an inversion of slope north of Lake Rogaguado, which embanked the valley and formed the lake. (b) A palaeocourse of the Beni River which has been cut by the lake. Topographic profiles are based on the Hole-filled SRTM version 4 (Jarvis et al., 2008). The image of the palaeo-Beni River in (b) is from Google Earth.

to the seasonally flooded backswamps of the ancient Beni River. The remains of the palaeochannel and levees of the ancient Beni River are still visible in the south-eastern margin of the lake (Fig. 10b). The stratigraphic units (as inferred from changes in colour and material) of core 398 correlate with those of core 397 , which is located about $6.6 \mathrm{~km}$ further south. Figure 11 shows the two cores in their relative position. At the time of the coring, the depth of the water at 397 was $2.4 \mathrm{~m}$. Assuming that the clay layer separating the terrestrial phase from the lacustrine one has, in this core, a similar thickness to that in core 398, the depth of the palaeosol can be estimated as being $3 \mathrm{~m}$ below the water level. The slope of the palaeosol below the lake, $0.0045 \%$ $(30 \mathrm{~cm}$ in $6.6 \mathrm{~km})$, is consistent with the average slope of the valley northward from the lake. This suggests that the lake was formed by an uplift on its northern side, causing the tilting that dammed the valley. However, the depth of the palaeosol with respect to the savannah south of the lake indicates also the presence of a normal fault, with a southern footwall and a throw between 2 and $3 \mathrm{~m}$, which probably defined the lake's southern border. The point where the valley's slope changes is about $8 \mathrm{~km}$ south of the lake's shore, coinciding with the sharp change in the direction of the Yata River (black arrow in Fig. 10). This data suggests that the formation of Lake Rogaguado, and probably of Lake Ginebra too, is the product of a combination of tilting and faulting, maybe resulting from an extensional setting related to an upward pulling north of the lake. In core 398 , radiocarbon dating of a wood fragment from the bottom of the lacustrine phase yields the age of $5791 \pm 155 \mathrm{cal} \mathrm{yr} \mathrm{BP}$, while the palaeosol that corresponds to the top of the terrestrial phase has been dated $10910 \pm 124 \mathrm{cal} \mathrm{yr}$ BP. The radiocarbon age of the palaeosol is based only on the soluble fraction, because no humins could be retrieved. Therefore, it should be interpreted as the average age of the palaeosol and not as the age of its burial. The palaeosol is separated from the organic sediments of the lacustrine phase by a $6 \mathrm{~cm}$ thick layer of clays and silts. This layer of sediments contains no organic matter, suggesting it was deposited soon after formation of the lake in a quick event. The sediments could have come from the erosion of the recently formed lake shores. This preliminary data suggests that Lake Rogaguado was formed in the mid-Holocene. There is a group of ria lakes that have not yet been described. They are located on the eastern margin of the Mamoré River, north of Puerto Siles (Fig. 10). Lake Oceano is the largest. The damming of the valleys that formed these lakes was likely caused by the infilling of the valleys' bottom with sediments from the Mamoré river. Lake Oceano offers a modern analogue of the formation of ria lakes in the southeastern LM by Grande River.

\section{Discussion}

In the present paper, geomorphological evidence of neotectonics in southern Amazonia is reviewed and corroborated with new data obtained from the analysis of remote sensing imagery and field work. A first attempt to establish the extent and timing of the neotectonic activity is made. Here, the three research questions formulated in the introduction are addressed in light of the new evidence presented. 


\subsection{What could be the general mechanism behind neotectonics in southern Amazonia?}

None of the two mechanisms proposed in previous studies as being behind neotectonic activity in the LM, the reactivation of the Tapajó fault in central Brazil (Dumont and Fournier, 1994) and the uplift of the Andean forebulge (Aalto et al., 2003), seem to be able to explain all the geomorphological evidence of neotectonics reviewed here. The reactivation of a supposed south-western extension of the Tapajó fault in central Brazil could explain the existence of a fault system along the Linea Bala-Rogaguado. However, it cannot explain the meandering pattern of the Mamoré River, which responds to uplifts occurring about 100 kilometres south (Fig. 6). Nor can it explain the closeness of the Brazilian Shield to the surface, and the outcropping of it in several locations in the south and south-east of the Linea Bala-Rogaguado. Moreover, the neotectonic setting in the Tapajó region is constituted by two grabens trending NW-SE and NNE-SSW and a set of ENEWSW strike-slip faults (Costa et al., 2001). It is unclear how these extensional structures in central Brazil could propagate into the normal faulting/tilting system associated with the Bala-Rogaguado region in northern Beni. Likewise, there is little evidence of uplift along the forebulge axis as identified by Aalto et al. (2003) (Fig. 1b). The presence of the Andean forebulge can explain the uplift at Puerto Siles and the consequent change in the behaviour of the Mamoré River. However, it is not compatible with the region's overall fluvial pattern and the topography of the LM. The uplift of the forebulge is very small (a few hundred metres over a distance of several hundred kilometres) and an inherited (preflexural) topographic relief can be more important than the forebulge in determining the drainage divide (Garcia-Castellanos and Cloetingh, 2011). Nevertheless, in models of continental and exorheic basins, the effect of the forebulge on the drainage network is generally evident (Garcia-Castellanos, 2002). In an extremely flat landscape, such as that of the LM, an uplift along the forebulge axes which is able to create the Puerto Siles knickpoint would be visible in the subsequent formation of a divergent drainage network. Yet, along the alleged forebulge axes, rivers, and even recent small drainage creeks, seem to be unaffected by the forebulge. In addition (i) some of the lowest-lying areas of the LM are found right along the forebulge, which is very unusual for an uplifting region and (ii) the alleged forebulge would be orthogonal to the Linea Bala-Rogaguado, therefore unable to explain the formation of the ria lakes.

This study suggests that the uplifting Fitzcarrald Arch is the most likely mechanism behind the observed uplift along the Linea Bala-Rogaguado, the general topography of the LM, the outcropping of the basement in the northern LM, the presence of underfit rivers crossing the savannahs in the transitional zone, the meandering pattern of the Mamoré River and the general shape of the fluvial network. The fault that caused the change in the direction of the

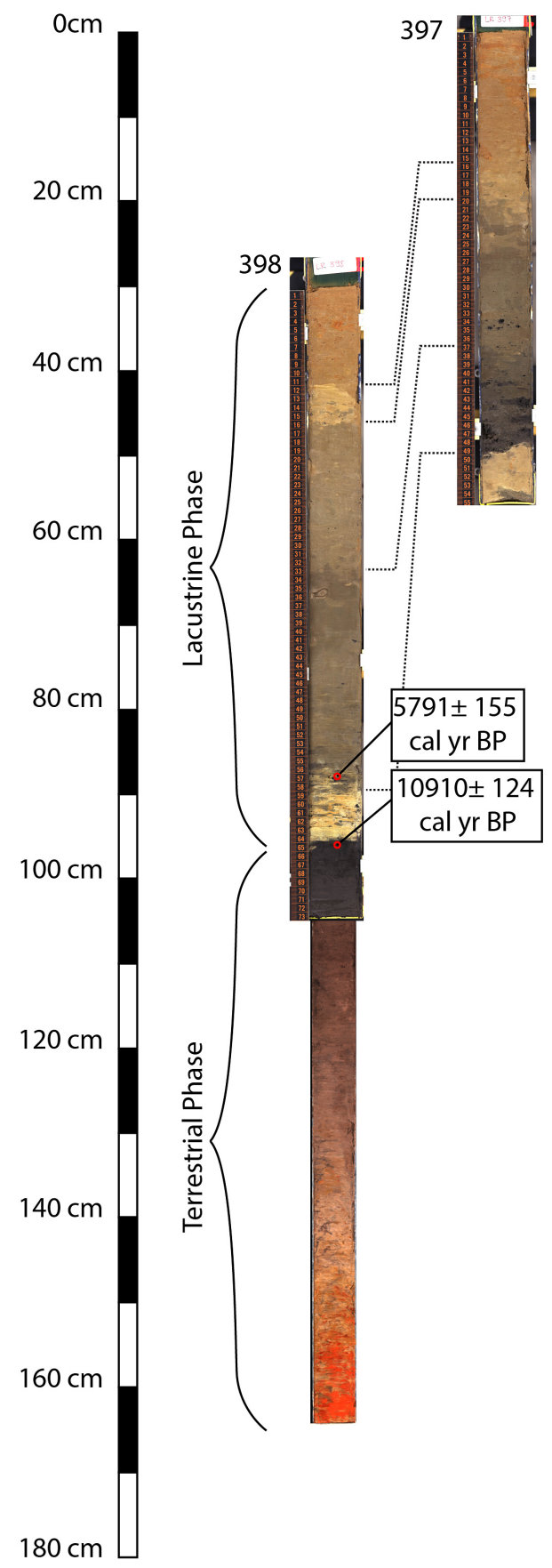

Figure 11. Cores from Lake Rogaguado. Core 398 includes a top part, which is the lacustrine phase that followed the formation of the lake, and a bottom part, which is the terrestrial phase which preceded the formation of the Lake. The red mottling at the base of the core indicates alternation of wet and dry periods, suggesting that savannah-like conditions prevailed in the backswamps of the palaeo-Beni River. The age of the beginning of the lacustrine phase is based on an AMS radiocarbon analysis of a wood sample performed at LARA AMS Laboratory in Bern (uncalibrated age $5104 \pm 76 \mathrm{yr}$ BP). The AMS radiocarbon age of the fossil Ah was measured by DirectAMS using the humate fraction (uncalibrated age $9685 \pm 40 \mathrm{yr}$ BP). 
Mamoré River (Fig. 5, reach 4) and the direction of the Linea Bala-Rogaguado, is consistent with the orientation of the Nazca Ridge, suggesting that the Nazca Ridge subduction is the most likely mechanism behind the tilting/uplift along the Linea Bala-Rogaguado. The backward sedimentation induced by the rapid uplift of the Fitzcarrald Arch could have buried and hidden the Andean forebulge.

In more general terms, the Bolivian Amazon can be divided into two areas under different depositional regimes: the uplifting north, crossed by incising rivers, which includes Pando and the northern LM; and the subsiding central and southern LM which are crossed by free meandering rivers. These two settings are the expression in the surface of the flat slab subduction in the north and normal subduction in the south. These two areas are separated by a transitional zone, which is flat, crossed by underfit rivers and also uplifting.

\subsection{What is the extent and timing of the neotectonic activity?}

It is unlikely that the different neotectonic elements of the landscape that have been reviewed here (the formation of ria lakes, the uplifted transitional zone, the avulsions of the Beni River, the formation of interior deltas and the changes in the meandering pattern of the Mamoré) River all happened at the same time and are the result of the same tectonic event. The data here presented suggest that the most likely scenario is that several tectonic events created and modified lakes and rivers at different times. The radiocarbon ages from the bottom of the lacustrine phase of Lake Rogaguado (which indicate that the lake formed about $6000 \mathrm{BP}$ ) and the radiocarbon ages of the palaeosols underlying fluvial deposits in central LM (which point to a mid- to late Holocene burial of the palaeosol) are, for now, the only fixed elements around which a relative chronology can be built. The formation of Lake Rogaguado is here interpreted as the last step in a series of correlated events.

\subsubsection{Pleistocene}

At the end of the Pleistocene, the Beni River flowed from east to west, up to a few kilometres north of Santa Ana de Yacuma, and then turned north in what is the modern Mamoré (Fig. 12a). The sediments that constitute the fluvial levees north of Puerto Siles (Fig. 7c) were probably deposited by the Beni River at this time. The Mamoré River used to flow further east, following the course now occupied by the far smaller Machupo River. Grande River was not a tributary of the Mamoré, but travelled north, discharging into the Iténez River, as well as the Mamoré (Fig. 12a).

\subsubsection{Early Holocene}

Probably during the late Pleistocene or at the beginning of the Holocene, and because of a fault along the Andean pied-

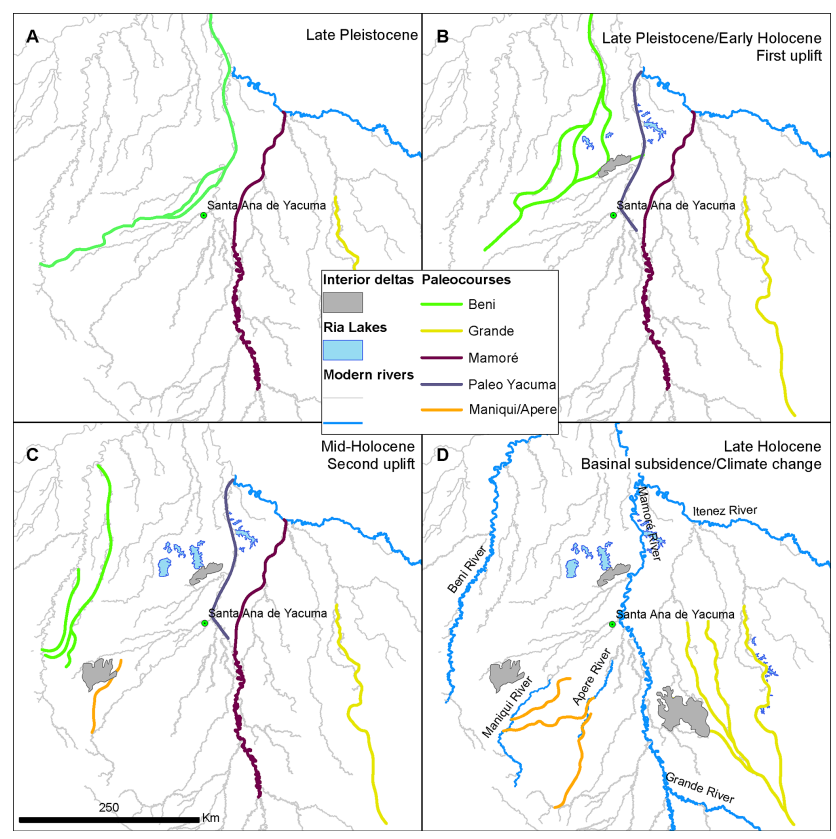

Figure 12. Reconstruction of the evolution of the landscape in the LM since the late Pleistocene. (a) shows the situation during the late Pleistocene with the Beni River flowing in what is now the Mamoré channel and the Mamoré River flowing towards the Iténez. Also the Grande River had a different course, flowing north into the Iténez. (b) shows the changes that followed the first uplift, with the Beni River shifting counterclockwise and the formation of a first group of ria lakes (Lake Oceano, Agua Clara and Largo). The crevasse splay of the Beni River in Fig. 3b probably formed during this time too. (c) shows how the Beni River shifted further west and how a second uplift formed the lakes Rogaguado and Ginebra. The DFS of the Maniqui River started forming at this time. (d) shows the modern setting, as it established during the late Holocene.

mont (Dumont, 1996), the River Beni shifted and occupied the valleys where, later, the lakes Rogaguado and Ginebra formed (Fig. 12b). Interestingly, the western border of the transitional zone coincides with the north-south oriented fault thought to have caused the migration of the deflection point of the Beni River, suggesting that the uplift of the transitional zone controlled the evolution of the Beni River. The same event also reduced the slope of the Maniqui River, inducing the formation of the Maniqui interior delta shown in Fig. 3d. During this time, the Beni River, and probably also the other rivers, was incising the northern LM in relatively deep valleys, also inducing erosion of the lateral valleys. Stratigraphic cores of these structures would allow us to date the underlying palaeosols and the time of the formation of both the Maniqui Delta and the Beni crevasse, allowing us to test whether or not their formation followed neotectonic uplifts. Palaeo-ecological records indicate that during the last glacial period (45.0-12.2 kyr BP) the climate in the LM was much drier than during the Holocene (Burbridge et al., 2004; Whitney et al., 2011). The first uplifting event that 
can be deduced from the geomorphological evidence happened north of $12.5^{\circ} \mathrm{S}$ and could be related to the formation of the knickpoint at Guayaramerín (Fig. 5). This uplift caused the backward sedimentation of the Beni River that, damming its lateral valleys, formed the lakes Agua Clara and Largo. This event could also be responsible for the formation of Lake Oceano and the other small ria lakes on the eastern margin of the Mamoré River (Fig. 12b). Further cores from lakes Largo, Agua Clara, Oceano and Ginebra are needed in order to date the beginning of the lacustrine sedimentation in these lakes and establish a more reliable chronology of the uplift events.

\subsubsection{Mid-Holocene}

A second neotectonic event, about $6 \mathrm{kyr} \mathrm{BP}$, formed the knickpoint at Puerto Siles, caused the tilting along the Linea Bala-Rogaguado and formed the lakes Rogaguado and Ginebra (Fig. 12c). The further shift of the Beni River from the Rogaguado and Ginebra valleys towards its current position could have preceded or been synchronous to the BalaRogaguado tilting. Lake cores from oxbows located within ancient gallery forests of the Beni River palaeocourses could help determine the timing of the Beni River avulsions and whether the avulsions were synchronous to the formation of the ria lakes. After the first shift of the Beni and before the Mamoré moved to its modern position, the upper course of the modern Mamoré was occupied by an underfit river with a smaller catchment, here called the palaeo-Yacuma in Fig. 12b and c. The palaeo-Yacuma probably transported only fine sediments, because most of its catchment would have been within the LM. The tectonic events that created the lakes Agua Clara and Largo first and the lakes Rogaguado and Ginebra later, probably also dammed this small river, which, during the rainy seasons, became an ephemeral ria lake, resembling the lower sections of the modern Negro, Xingú and Tapajó rivers. During this period, clayish sediments could have deposited within the fluvial valley, forming the thick organic layers that outcrops today along the banks of the Mamoré. These layers have been interpreted as palaeosols formed in the floodplain during periods of reduced river sedimentation, (Plotzki, 2013). Along the bank of the Mamorè, about $50 \mathrm{~km}$ north of Santa Ana, the exposed organic layer is about $3 \mathrm{~m}$ thick, and radiocarbon data indicates it formed between 12 and $3 \mathrm{kyr} \mathrm{BP}$ (Plotzki, 2013). However, the thickness of these palaeosols suggests that they are cumulative palaeosols, where deposition and pedogenesis coexisted (Kraus and Aslan, 1993). Their formation could be better explained by two cyclical processes working at different timescales. On a century to millennium scale, periods of more severe water ponding could have been cyclically alternated with periods of increased drainage. Clays would deposit during periods of water ponding due to downriver uplifts. These uplift events would create knickpoints that the rivers would start to erode immediately; the modern ana- logues for this situation are the knickpoints at Puerto Siles and Guyaramerín (Fig. 5). The erosion of the knickpoint would increase the drainage, lower the level of the river, reduce the sedimentation and allow for soil formation. On a seasonal scale, clays would have been deposited during the rainy season, when water was ponded within the river valleys; wetlands would have formed during the dry season, following the lowering of the water table. These alternate phases of deposition of clays with soil formation could eventually form very thick layers of organic-rich clays as those found along the Mamoré banks. Evidence that uplift in the northern part of the LM could have induced water ponding, backward sedimentation and elevation of the water table several times during the Holocene, can also be seen in fossil wood (dated $5.575 \pm 105,7.145 \pm 150,9.995 \pm 150$ and $10.085 \pm 150 \mathrm{yr} \mathrm{BP}$ ) found embedded in clay layers along the rivers Acre, Beni and Madre de Dios (Campbell and Frailey, 1984; Campbell et al., 1985). According to Campbell, the presence of these clayey deposits over a very large area is indicative of a lacustrine depositional environment and is the result of the formation of a large lake, Lake Mojos, which would have had a southward drainage, belonging to the La Plata River basin (Campbell, 1989 cited in Hanagarth, 1993). It has been suggested that during the Holocene, the sedimentation of the Grande and Parapetí rivers closed the southern drainage and that Lake Mojos broke the northern enclosure, leading to the modern situation (Hanagart and Sarmiento, 1990). However, the existence of such a lake is at odds with the general topography of the Cerrado Beniano, which is crossed by many fluvial valleys and not just one, as it would be in the case of Campbell's reconstruction. Moreover, if Lake Mojos drained towards the south, we should find in the Cerrado Beniano a palaeodrainage network which converges toward the south, but, as shown in Fig. 9, this is not the case. As for the palaeosols along the Mamore, the presence of the layers of clay observed along many rivers in northern LM (Campbell and Frailey, 1984; Campbell et al., 1985), could be the result of water ponding and backwards sedimentations caused by downriver uplifts. If this hypothesis is correct, such deposits could serve as proxies to trace back neotectonic events.

\subsubsection{Late Holocene}

The situation of the Mamoré and Grande rivers did not change until the late Holocene, when the palaeo-Yacuma course was occupied by the Mamoré and the rest of the modern fluvial network was established (Fig. 12d). During the mid- to late Holocene, a large transformation occurred in the central and southern LM. Perhaps due to a climate shift towards wetter conditions (Lombardo et al., 2012; Plotzki et al., 2013), coupled with basinal subsidence (Hanagarth, 1993; Dumont and Fournier, 1994), the Mamoré established its modern position and the Grande River formed a large distributary system (Fig. 12d). It has also been suggested that, when the Grande River became a tributary of the 
Mamoré, the increased discharge triggered the Mamoré avulsion (Plotzki et al., 2013). This research shows that during the late Holocene, the western side of the LM was also subject to extensive fluvial depositions and the formation of distributary systems in the case of the rivers Maniqui and Apere, as indicated by the recurrent palaeosols shown in Fig. 4. As for the avulsion of the Grande River and for the fluvial deposition in the western LM, there is insufficient data yet to establish whether it was caused by an increase in precipitation, basinal subsidence or a combination of both.

\subsection{How did neotectonics affect the LM hydrology during the Holocene?}

\subsubsection{Hydrology and landscape}

The Fitzcarrald Arch's uplift played an important role in the evolution of the Amazon Basin and a major role in increasing its biodiversity (Espurt et al., 2010). However, in the case of the Bolivian Amazon, its effects have not yet been explored. Here, I suggest that the uplift of the Fitzcarrald Arch has determined the evolution of the landscape of the LM at both a regional and a local scale. Tectonics control the differences in soils and vegetation between the hilly landscape of the Cerrado Beniano, the flat and incised transitional zone, and the vast floodplain of the central and southern LM. In the Cerrado Beniano, the uplift causes the outcropping of lateritic crusts and the formation of a hilly topography, while, in the transitional zone, it prevents the deposition of fluvial sediments over the savannahs, with detrimental effects on soil fertility (Lombardo et al., 2013a). The southern LM is a subsiding area, therefore subjected to the deposition of recent fluvial sediments, and hence more fertile. The transition between the Cerrado Beniano and the central/southern LM is also the transition between the uplifting north and the subsiding south. This exerts an important control over the river network of the western LM, determining the underfitting of rivers that flow north at approximately $-14^{\circ} \mathrm{S}$. When the uplift causes a decrease in river slope, interior deltas and wetlands form, like the large interior delta of the Maniqui River which could have been induced by the uplift of the transitional zone.

The multiplying effect of precipitation on the severity of the floods, where an increase of less than $100 \%$ in mean annual precipitation causes the size of the flooded area to increase by more than $300 \%$, is caused by the extremely flat landscape in the LM. Precipitation alone would not cause any floods if the LM had a better drainage. The savannahforest ecotone in the central and southern LM is controlled by the duration and intensity of the seasonal floods (Mayle et al., 2007). Hamilton et al. (2004) have pointed out that the outcrops of the Brazilian Shield in the northern LM constrain the river channels and contribute to a backwater effect at high water. Therefore, as floods determine the savannahforest ecotone, drainage determines how floods respond to precipitation and neotectonics determines drainage, it can be concluded that uplifts in northern LM could have been a determining factor in the evolution of the savannah-forest ecotone in the central and southern LM during the Holocene. Uplift events in the northern LM reduced the drainage of the basin, but they were followed by stronger erosion by the rivers going through the uplifted rocks. This study suggests that uplifts were responsible for (1) the creation of interior deltas, (2) the elevation of the river beds with formation of ria lakes in some of the lateral valleys, and (3) the increase in sedimentation of fine silts and clays in the fluvial valleys, with a consequent flattening of the topography and creation of flat valley bottoms. Conversely, periods between different uplifts were characterized by deeper river incision, improved drainage, lowering of the LM water table, reduction of the flooded areas and widespread changes in the process of soil formation and vegetation assemblages. This interplay between uplift and river incision could have been, together with climate, a major player in controlling inundation patterns in the LM and the most important factor determining the evolution of the LM landscape. Moreover, the changes in river slope due to downriver uplifts would have had an impact on the sedimentary load of the Madeira River and, consequently, of the Amazon River, as neotectonics not only affects the shape and behaviour of channels and flood plains but also determines the river's suspended-load transport capacity (Dunne et al., 1998).

\subsubsection{Hydrology and people}

Likewise, as people lived in the LM since the early Holocene (Lombardo et al., 2013b), it is to be expected that neotectonics had important effects on pre-Columbian peoples too. There is very little data yet about early Holocene human presence in southern Amazonia, the only study published so far (Lombardo et al., 2013b) suggests that hunter-gatherers settled in the southern LM from 10500 till 4200 cal yr BP, approximately. It would seem that pre-Columbians were able to adapt to changes brought about by mid-Holocene neotectonic events; nevertheless, the formation of the Grande River megafan, approximately $4200 \mathrm{cal}$ yr BP, which buried the hunter-gatherer sites, was followed by a period of about $2000 \mathrm{yr}$ of archaeological hiatus. Although the specific cause behind the Grande River avulsion is unclear, it is evident that it is basinal subsidence that, accommodating the sediment charge, created the preconditions for the formation of megafans. It is likely that the deposition of fertile sediments in southern LM created the necessary conditions for the subsequent development of complex societies in the southeastern LM, the so-called Earthmovers, about 1400 cal yr BP (Lombardo et al., 2012). It has been suggested that, late Holocene pre-Columbian settlement patterns, adaptive strategies and social complexity followed ecological gradients of soil fertility and flood intensity (Lombardo et al., 2011b). The data here presented shows that these ecological 
gradients are, to a great extent, the expression of the underlying geological control.

\section{Conclusions}

This paper has reviewed the published evidence of neotectonic activity in southern Amazonia and integrated it with new data from the analysis of remote sensing imagery and extensive field work in the LM. Based on the study of modern and palaeorivers, ria lakes, palaeosols and landscape topography in this region, this paper suggests that the uplifting Fitzcarrald Arch is the most likely mechanism behind the observed uplift along the Linea Bala-Rogaguado, the general topography of the LM, the outcropping of the basement in the northern LM, the presence of underfit rivers crossing the savannahs in the transitional zone, the meandering pattern of the Mamoré River and the general shape of the fluvial network. I suggest that the tectonic regime brought about by the Fitzcarrald Arch has determined the hydrology, flooding patterns, the forest-savannah ecotone and overall evolution of the landscape of the LM at both a regional and a local scale. These findings stress that, contrary to what many researchers have assumed, climate and human activities have not been the only factors influencing landscape evolution in the Bolivian Amazon during the Holocene. On the contrary, the interplay between the Fitzcarrald Arch uplift and river incision could have played a fundamental role in the evolution of the LM's landscape since the late Pleistocene. It is unlikely that the different neotectonic elements of the landscape that have been reviewed here were caused by a single uplift. Instead, I propose a reconstruction of the evolution of the landscape of southern Amazonia in which at least two uplift events took place. More data is needed in order to confirm the hypothesis here presented and to better constrain the timing of the different events, such as the formation of ria lakes and interior deltas, river avulsions and deposition of crevasse spays. Nevertheless, the reconstruction here proposed represents a useful working model for future research and highlights the importance of taking into account neotectonics in palaeo-environmental reconstructions of southern Amazonia. In addition, this work highlights the need to disentangle the effects of human populations, climate change and neotectonics on the evolution of the LM, in order to better predict the impact of future climate change in the region and develop better adaptation strategies for local communities.

Acknowledgements. The present study has been funded by the Swiss National Science Foundation (SNSF), grants no. 200020 and 141277/1. I would like to thank H. Veit for his support and guidance. Lake Rogaguado has been cored in collaboration with the IRD project HydroGen; M. Grosjean and M-P. Ledru lent me the coring devices and taught me how to use them. L. Rodrigues and A. Giesche helped in several aspects of the fieldwork; J. Bocchetti helped me with several logistical problems in the field, including the fixing of the Waker motor. I am very grateful for the hospitality of the Community of Coquinal and, very specially, to Jonny Ibáñez, who pulled our car out of a crocodile-infested pond in the middle of the night. Further thanks are also due to E. Canal-Beeby, D. Garcia-Castellanos, J. Carson, the editor, S. Mudd, and two anonymous reviewers who helped improve earlier versions of the manuscript.

Edited by: S. Mudd

\section{References}

Aalto, R., Maurice-Bourgoin, L., Dunne, T., Montgomery, D. R., Nittrouer, C. A., and Guyot, J.-L.: Episodic sediment accumulation on Amazonian flood plains influenced by El Niño/Southern Oscillation, Nature, 425, 493-497, doi:10.1038/nature01990, 2003.

Allenby, R. J.: Origin of rectangular and aligned lakes in the Beni Basin of Bolivia, Tectonophysics, 145, 1-20, 1988.

Angermeier, P. L.: The Natural Imperative for Biological Conservation, Conserv. Biol., 14, 373-381, doi:10.1046/j.15231739.2000.98362.x, 2000.

Behling, H., Keim, G., Irion, G., Junk, W., and Nunes de Mello, J.: Holocene environmental changes in the Central Amazon Basin inferred from Lago Calado (Brazil), Palaeogeogr. Palaeocl., 173, 87-101, 2001.

Baker, V. R.: Adjustment of fluvial systems to climate and source terrain in tropical and subtropical environments, in: Fluvial Sedimentology, edited by: Miall, A. D., Memoir-Canadian Society of Petroleum Geologists, 211-230, 1977.

Boixadera, J., Poch, R. M., García-González, M. T., and Vizcayno, C.: Hydromorphic and clay-related processes in soils from the Llanos de Moxos (northern Bolivia), Catena, 54, 403424, doi:10.1016/s0341-8162(03)00134-6, 2003.

Bourrel, L. and Pouilly, M.: Hidrología y dinámica fluvial del Río Mamoré, in: Diversidad biológica en la llanura de inundación del Río Mamoré, edited by: Pouilly, M., Beck, S., Moraes, M., and Ibañez, C., Centro de Ecología Simón I. Patiño, Santa Cruz, Bolivia, 95-116, 2004.

Bourrel, L., Phillips, L., and Moreau, S.: The dynamics of floods in the Bolivian Amazon Basin, Hydrol. Process., 23, 3161-3167, doi:10.1002/hyp.7384, 2009.

Bridge, J. S.: Rivers and floodplains: forms, processes, and sedimentary record, John Wiley \& Sons, Oxford, UK, 2009.

Buehler, H. A., Weissmann, G. S., Scuderi, L. A., and Hartley, A. J.: Spatial and Temporal Evolution of an Avulsion on the Taquari River Distributive Fluvial System from Satellite Image Analysis, Journal of Sediment. Res., 81, 630-640, doi:10.2110/jsr.2011.040, 2011.

Burbank, D. W. and Anderson, R. S.: Tectonic geomorphology, John Wiley \& Sons, Chichester, UK, 2011.

Burbridge, R. E., Mayle, F. E., and Killeen, T. J.: Fifty-thousandyear vegetation and climate history of Noel Kempff Mercado National Park, Bolivian Amazon, Quaternary Res., 61, 215-230, doi:10.1016/j.yqres.2003.12.004, 2004.

Bush, M. B. and Silman, M. R.: Amazonian exploitation revisited: ecological asymmetry and the policy pendulum, Front. Ecol. Environ., 5, 457-465, doi:10.1890/070018, 2007. 
Campbell, K. E. and Frailey, C. D.: Holocene flooding and species diversity in southwestern Amazonia, Quaternary Res., 21, 369375, doi:10.1016/0033-5894(84)90075-9, 1984.

Campbell, K. E., Frailey, C. D., and Arellano, J. L.: The geology of the Rio Beni: Further evidence for Holocene flooding in Amazonia, Contributions in Science, Natural History Museum of Los Angeles County, 364, 1-18, 1985.

Carson, J. F., Whitney, B. S., Mayle, F. E., Iriarte, J., Prümers, H., Soto, J. D., and Watling, J.: Environmental impact of geometric earthwork construction in pre-Columbian Amazonia, P. Natl. Acad. Sci., 11, 10497-10502, doi:10.1073/pnas.1321770111, 2014

Costa, J. B. S., Léa Bemerguy, R., Hasui, Y., and da Silva Borges, M. C.: Tectonics and paleogeography along the Amazon river, J. S. Am. Earth Sci., 14, 335-347, doi:10.1016/s08959811(01)00025-6, 2001.

Dearing, J. A.: Landscape change and resilience theory: a palaeoenvironmental assessment from Yunnan, SW China, The Holocene, 18, 117-127, doi:10.1177/0959683607085601, 2008.

DeCelles, P. G. and Giles, K. A.: Foreland basin systems, Basin Research, 8, 105-123, doi:10.1046/j.1365-2117.1996.01491.x, 1996.

Dumont, J. F.: Type of lakes as related to neotectonics in western Amazonia, International symposium on the Quaternary of Amazonia, 8-13 November 1992, Manaus, Brazil, 1993

Dumont, J. F.: Neotectonics of the Subandes-Brazilian craton boundary using geomorphological data: the Marañon and Beni basins, Tectonophysics, 257, 137-151, 1996.

Dumont, J. F. and Fournier, M.: Geodynamic environment of Quaternary morphostructures of the subandean foreland basins of Peru and Bolivia: Characteristics and study methods, Quatern. Int., 21, 129-142, doi:10.1016/1040-6182(94)90027-2, 1994.

Dumont, J. F. and Guyot, J. L.: Ria lac: ou, pourquoi?, Proceedings of the Third International Conference on Geomorphology, 23-29 August, 1993, Hamilton, Canada, 1993,

Dunne, T., Mertes, L. A. K., Meade, R. H., Richey, J. E., and Forsberg, B. R.: Exchanges of sediment between the flood plain and channel of the Amazon River in Brazil, Geol. Soc. Am. Bull., 110, 450-467, doi:10.1130/0016-7606(1998)110<0450:eosbtf> 2.3.co;2, 1998.

Erickson, C. L.: Amazonia: the historical ecology of a domesticated landscape, in: Handbook of South American archaeology, edited by: Silverman, H. and Isbell, W. H., Springer, Berlin, 157-183, 2008.

Espurt, N., Baby, P., Brusset, S., Roddaz, M., Hermoza, W., Regard, V., Antoine, P. O., Salas-Gismondi, R., and Bolaños, R.: How does the Nazca Ridge subduction influence the modern Amazonian foreland basin?, Geology, 35, 515-518, doi:10.1130/g23237a.1, 2007.

Espurt, N., Funiciello, F., Martinod, J., Guillaume, B., Regard, V., Faccenna, C., and Brusset, S.: Flat subduction dynamics and deformation of the South American plate: Insights from analog modeling, Tectonics, 27, TC3011, doi:10.1029/2007tc002175, 2008.

Espurt, N., Baby, P., Brusset, S., Roddaz, M., Hermoza, W., and Barbarand, J.: The Nazca Ridge and Uplift of the Fitzcarrald Arch: Implications for Regional Geology in Northern South America, in: Amazonia: Landscape and Species Evolu- tion, edited by: Hoorn, C. and Wesselingh, F. P., Wiley-Blackwell Publishing Ltd., Oxford, UK, 89-100, 2010.

Fan, Y., Li, H., and Miguez-Macho, G.: Global Patterns of Groundwater Table Depth, Science, 339, 940-943, doi:10.1126/science.1229881, 2013.

Garcia-Castellanos, D.: Interplay between lithospheric flexure and river transport in foreland basins, Basin Research, 14, 89-104, doi:10.1046/j.1365-2117.2002.00174.x, 2002.

Garcia-Castellanos, D. and Cloetingh, S.: Modeling the Interaction between Lithospheric and Surface Processes in Foreland Basins, in: Tectonics of Sedimentary Basins, John Wiley \& Sons Ltd., Chichester, UK, 152-181, 2011.

Gupta, A.: Tropical geomorphology, Cambridge University Press, New York, USA, 2011.

Hajek, E. A. and Edmonds, D. A.: Is river avulsion style controlled by floodplain morphodynamics?, Geology, 42, 199-202, doi:10.1130/g35045.1, 2014.

Hamilton, S. K., Sippel, S. J., and Melack, J. M.: Seasonal inundation patterns in two large savanna floodplains of South America: the Llanos de Moxos(Bolivia) and the Llanos del Orinoco (Venezuela and Colombia), Hydrol. Process., 18, 2103-2116, doi:10.1002/hyp.5559, 2004.

Hanagart, W. and Sarmiento, J.: Reporte preliminar sobre la geoecología de la sabana de Espíritu y sus alrededores (Llanos de Moxos, departamento del Beni, Bolivia), Ecología en Bolivia, 16, 47-75, 1990.

Hanagarth, W.: Acerca de la geoecología de las sabanas del Beni en el noreste de Bolivia, Instituto de ecología, La Paz, Bolivia, 1993.

Hartley, A. J., Weissmann, G. S., Nichols, G. J., and Warwick, G. L.: Large Distributive Fluvial Systems: Characteristics, Distribution, and Controls on Development, J. Sediment. Res., 80, 167-183, doi:10.2110/jsr.2010.016, 2010.

Herzog, S., Maillard Z, O., Embert, D., Caballero, P., and Quiroga, D.: Range size estimates of Bolivian endemic bird species revisited: the importance of environmental data and national expert knowledge, J. Ornithol., 153, 1189-1202, doi:10.1007/s10336012-0850-2, 2012.

Hogg, A. G., Hua, Q., Blackwell, P. G., Niu, M., Buck, C. E., Guilderson, T. P., Heaton, T. J., Palmer, J. G., Reimer, P. J., Reimer, R. W., Turney, C. S. M., and Zimmerman, S. R. H.: SHCal13 Southern Hemisphere Calibration, 0-50 000 Years cal BP, Radiocarbon, 55, 1889-1903, 2013.

Holbrook, J. and Schumm, S. A.: Geomorphic and sedimentary response of rivers to tectonic deformation: a brief review and critique of a tool for recognizing subtle epeirogenic deformation in modern and ancient settings, Tectonophysics, 305, 287-306, 1999.

Irion, G., Bush, M. B., Nunes de Mello, J. A., Stüben, D., Neumann, T., Müller, G., Morais de, J. O., and Junk, J. W.: A multiproxy palaeoecological record of Holocene lake sediments from the Rio Tapajós, eastern Amazonia, Palaeogeogr. Palaeocl., 240, 523-535, doi:10.1016/j.palaeo.2006.03.005, 2006.

Irion, G., Mello, J. S. N., Morais, J., Piedade, M. F., Junk, W., and Garming, L.: Development of the Amazon Valley During the Middle to Late Quaternary: Sedimentological and Climatological Observations, in: Amazonian Floodplain Forests, edited by: Junk, W. J., Piedade, M. T. F., Wittmann, F., Schöngart, J., 
and Parolin, P., Ecological Studies, Springer Netherlands, 27-42, 2011.

Jarvis, A., Reuter, H. I., Nelson, A., and Guevara, E.: Hole-filled SRTM for the globe Version 4, available atthe CGIARCSI SRTM 90m Database: http://srtm.csi.cgiar.org (last access: 15 December 2014), 2008.

Junk, W.: Current state of knowledge regarding South America wetlands and their future under global climate change, Aquatic Sciences - Research Across Boundaries, 75, 113-131, doi:10.1007/s00027-012-0253-8, 2013.

Junk, W. J., Bayley, P. B., and Sparks, R. E.: The flood pulse concept in river-floodplain systems, Canadian special publication of fisheries and aquatic sciences, 106, 110-127, 1989.

Kraus, M. J. and Aslan, A.: Eocene hydromorphic Paleosols; significance for interpreting ancient floodplain processes, J. Sediment. Res., 63, 453-463, doi:10.1306/d4267b22-2b26-11d78648000102c1865d, 1993.

Langstroth, R. P.: Forest islands in an Amazonian savanna of northeastern Bolivia, University of Wisconsin-Madison, Unpublished PhD dissertation, 1996.

Langstroth, R. P.: Biogeography of the Llanos de Moxos: natural and anthropogenic determinants, Geographica Helvetica, 66, 183-192, 2011.

Latrubesse, E. M. and Franzinelli, E.: The Holocene alluvial plain of the middle Amazon River, Brazil, Geomorphology, 44, 241257, doi:10.1016/S0169-555X(01)00177-5, 2002.

Latrubesse, E. M., Cozzuol, M., da Silva-Caminha, S. A. F., Rigsby, C. A., Absy, M. L., and Jaramillo, C.: The Late Miocene paleogeography of the Amazon Basin and the evolution of the Amazon River system, Earth-Sci. Rev., 99, 99-124, doi:10.1016/j.earscirev.2010.02.005, 2010.

Lombardo, U. and Prümers, H.: Pre-Columbian human occupation patterns in the eastern plains of the Llanos de Moxos, Bolivian Amazonia, J. Archaeol. Sci., 37, 1875-1885, doi:10.1016/j.jas.2010.02.011, 2010.

Lombardo, U. and Veit, H.: The origin of oriented lakes: Evidence from the Bolivian Amazon, Geomorphology, 204, 502509, doi:10.1016/j.geomorph.2013.08.029, 2014.

Lombardo, U., Canal-Beeby, E., Fehr, S., and Veit, H.: Raised fields in the Bolivian Amazonia: a prehistoric green revolution or a flood risk mitigation strategy?, J. Archaeol. Sci., 38, 502-512, doi:10.1016/j.jas.2010.09.022, 2011a.

Lombardo, U., Canal-Beeby, E., and Veit, H.: Eco-archaeological regions in the Bolivian Amazon: Linking pre-Columbian earthworks and environmental diversity, Geographica Helvetica, 66, 173-182, 2011b.

Lombardo, U., May, J.-H., and Veit, H.: Mid- to late-Holocene fluvial activity behind pre-Columbian social complexity in the southwestern Amazon basin, The Holocene, 22, 1035-1045, doi:10.1177/0959683612437872, 2012.

Lombardo, U., Denier, S., May, J.-H., Rodrigues, L., and Veit, H.: Human-environment interactions in pre-Columbian Amazonia: The case of the Llanos de Moxos, Bolivia, Quatern. Int., 312, 109-119, doi:10.1016/j.quaint.2013.01.007, 2013a.

Lombardo, U., Szabo, K., Capriles, J. M., May, J.-H., Amelung, W., Hutterer, R., Lehndorff, E., Plotzki, A., and Veit, H.: Early and Middle Holocene Hunter-Gatherer Occupations in Western Amazonia: The Hidden Shell Middens, PLoS ONE, 8, e72746, doi:10.1371/journal.pone.0072746, 2013 b.
Lombardo, U., Denier, S., and Veit, H.: Soil properties and preColumbian settlement patterns in the Monumental Mounds Region of the Llanos de Moxos, Bolivian Amazon, SOIL Discuss., 1, 81-117, doi:10.5194/soild-1-81-2014, 2014.

Mann, C. C.: Ancient earthmovers of the Amazon, Science, 321, 1148-1152, 2008.

Mayle, F. E., Burbridge, R., and Killeen, T. J.: Millennial-scale dynamics of southern Amazonian rain forests, Science, 290, 22912294, doi:10.1126/science.290.5500.2291, 2000.

Mayle, F. E., Langstroth, R. P., Fisher, R. A., and Meir, P.: Longterm forest-savannah dynamics in the Bolivian Amazon: implications for conservation, Philos. T. Roy. Soc. B., 362, 291-307, doi:10.1098/rstb.2006.1987, 2007.

Melack, J. and Hess, L.: Remote Sensing of the Distribution and Extent of Wetlands in the Amazon Basin, in: Amazonian Floodplain Forests, edited by: Junk, W. J., Piedade, M. T. F., Wittmann, F., Schöngart, J., and Parolin, P., Ecological Studies, Springer Netherlands, 43-59, 2011.

Navarro, G.: Clasificación de la vegetación de Bolivia, Centro de ecología difusión fundación Simón I. Patiño, Santa Cruz, Bolivia, 2011.

Pitfield, P. E. J. and Power, G.: Geologic map MagdalenaSD 20-6 con parte de SD 20-2, Ordnance Survey 4/88/880413S, Southampton, UK, 1987.

Plafker, G.: Oriented Lakes and Lineaments of Northeastern Bolivia, Geol. Soc. Am. Bull., 75, 503-522, doi:10.1130/00167606(1964)75[503:olalon]2.0.co;2, 1964.

Plafker, G.: Tectonic implications of the oriented lakes and lineaments in northeastern Bolivia, First International Conference on the New Basement Tectonics, Salt Lake City, Utah, USA, 519527, 1974.

Plotzki, A.: Late Pleistocene to Holocene fluvial dynamics and environmental conditions in the Llanos de Moxos, Bolivian Amazon, PhD, Philosophisch naturwissenschaftlichen Fakultät, Universität Bern, Bern, Switzerland, 2013.

Plotzki, A., May, J. H., and Veit, H.: Past and recent fluvial dynamics in the Beni lowlands, NE Bolivia, Geographica Helvetica, 66, 164-172, 2011.

Plotzki, A., May, J. H., Preusser, F., and Veit, H.: Geomorphological and sedimentary evidence for late Pleistocene to Holocene hydrological change along the Río Mamoré, Bolivian Amazon, J. S. Am. Earth Sci., 47, 230-242, doi:10.1016/j.jsames.2013.08.003, 2013.

Räsänen, M. E., Salo, J. S., and Kalliola, R. J.: Fluvial Perturbance in the Western Amazon Basin: Regulation by Long-Term Sub-Andean Tectonics, Science, 238, 1398-1401, doi:10.1126/science.238.4832.1398, 1987.

Regard, V., Lagnous, R., Espurt, N., Darrozes, J., Baby, P., Roddaz, M., Calderon, Y., and Hermoza, W.: Geomorphic evidence for recent uplift of the Fitzcarrald Arch (Peru): A response to the Nazca Ridge subduction, Geomorphology, 107, 107-117, doi:10.1016/j.geomorph.2008.12.003, 2009.

Roddaz, M., Brusset, S., Baby, P., and Herail, G.: Miocene tidalinfluenced sedimentation to continental Pliocene sedimentation in the forebulge-backbulge depozones of the Beni-Mamore foreland Basin (northern Bolivia), J. S. Am. Earth Sci., 20, 351-368, doi:10.1016/j.jsames.2005.11.004, 2006. 
Ronchail, J. and Gallaire, R.: ENSO and rainfall along the Zongo valley (Bolivia) from the Altiplano to the Amazon basin, Int. J. Climatol., 26, 1223-1236, doi:10.1002/joc.1296, 2006.

Ronchail, J., Bourrel, L., Cochonneau, G., Vauchel, P., Phillips, L., Castro, A., Guyot, J., and Deoliveira, E.: Inundations in the Mamoré basin (south-western Amazon-Bolivia) and seasurface temperature in the Pacific and Atlantic Oceans, J. Hydrol., 302, 223-238, doi:10.1016/j.jhydrol.2004.07.005, 2005.

Rossetti, D. F., Zani, H., Cohen, M. C. L., and Cremon, É. H.: A Late Pleistocene-Holocene wetland megafan in the Brazilian Amazonia, Sedimentary Geology, 282, 276-293, doi:10.1016/j.sedgeo.2012.09.015, 2012.

Schumm, S. A., Dumont, J. F., and Holbrook, J. M.: Active tectonics and alluvial rivers, Cambridge University Press, Cambridge, UK, 2002.

Slingerland, R. and Smith, N. D.: River Avulsions and their deposits, Ann. Rev. Earth Planet. Sci., 32, 257-285, doi:10.1146/annurev.earth.32.101802.120201, 2004.

Tinner, W. and Ammann, B.: Long-term Responses of Mountain Ecosystems to Environmental Changes: Resilience, Adjustment, and Vulnerability, in: Global Change and Mountain Regions, edited by: Huber, U., Bugmann, H. M., and Reasoner, M., Advances in Global Change Research, Springer Netherlands, 133143, 2005.

UNASBVI-JICA: Estudio Hidrogeologico de Beni y Pando, Trinidad-Bolivia, 2009.

Urrego, D. H., Bush, M. B., Silman, M. R., Niccum, B. A., De La Rosa, P., McMichael, C. H., Hagen, S., and Palace, M.: Holocene fires, forest stability and human occupation in south-western Amazonia, J. Biogeogr., 40, 521-533, doi:10.1111/jbi.12016, 2013.

Vegas-Vilarrúbia, T., Rull, V., Montoya, E., and Safont, E.: Quaternary palaeoecology and nature conservation: a general review with examples from the neotropics, Quaternary Sci. Rev., 30, 2361-2388, doi:10.1016/j.quascirev.2011.05.006, 2011.
Walker, J.: Agricultural Change in the Bolivian Amazon, Memoirs in Latin American Archaeology, University of Pittsburgh Latin American Archaeology Publications and Fundación Kenneth Lee, Trinidad, 2004.

Wallace, R., Martinez, J., Lopez-Strauss, H., Barreta, J., Reinaga, A., and Lopez, L.: Conservation Challenges Facing Two Threatened Endemic Titi Monkeys in a Naturally Fragmented Bolivian Forest, in: Primates in Fragments, edited by: Marsh, L. K. and Chapman, C. A., Developments in Primatology: Progress and Prospects, Springer New York, 493-501, 2013.

Weissmann, G. S., Hartley, A. J., Nichols, G. J., Scuderi, L. A., Olson, M., Buehler, H., and Banteah, R.: Fluvial form in modern continental sedimentary basins: Distributive fluvial systems, Geology, 38, 39-42, doi:10.1130/g30242.1, 2010.

Weissmann, G., Hartley, A., Scuderi, L., Nichols, G., Davidson, S., Owen, A., Atchley, S., Bhattacharya, J., Chakraborty, T., and Ghosh, P.: Prograding distributive fluvial systems: geomorphic models and ancient examples, New Frontiers in Paleopedology and Terrestrial Paleoclimatology: SEPM, Special Publication, 104, 131-147, 2013.

Whitney, B. S., Mayle, F. E., Punyasena, S. W., Fitzpatrick, K. A., Burn, M. J., Guillen, R., Chavez, E., Mann, D., Pennington, R. T., and Metcalfe, S. E.: A $45 \mathrm{kyr}$ palaeoclimate record from the lowland interior of tropical South America, Palaeogeogr. Palaeocl., 307, 177-192, doi:10.1016/j.palaeo.2011.05.012, 2011.

Willis, K. J. and Birks, J.-B.: What is natural? The need for a long-term perspective in biodiversity conservation, Science, 314 , 1261-1265, 2006. 